МИНИСТЕРСТВО ЗДРАВООХРАНЕНИЯ РОССИЙСКОЙ ФЕДЕРАЦИИ

ФГБОУ ВО «Саратовский ГМУ им. В.И. Разумовского» Минздрава России Кафедра факультетской терапии лечебного факультета

\author{
Е.А. Наумова, Ю.Г. Шварц, \\ Н.А. Железнякова, О.Н. Семенова
}

\title{
ТЕСТЫ И ЗАДАЧИ ПО КАРДИОЛОГИИ
}

Учебное пособие

Рекомендовано УМО РАЕ

по классическому университетскому

и техническому образованию

в качестве учебного пособия

для ординаторов, обучающихся

по специальностям:

31.08 .49 - «Терапия»;

31.08.36 - «Кардиология» 
УДК 616-085:612.17]-004.054 (075.9)

ББК 54.10я73

T367

\section{Aвторы:}

Наумова Елизавета Александровна - доктор медицинских наук, профессор кафедры факультетской терапии лечебного факультета Саратовского ГМУ им. В.И. Разумовского Минздрава России;

Шварц Юрий Григорьевич - доктор медицинских наук, профессор, заведующий кафедрой факультетской терапии лечебного факультета Саратовского ГМУ им. В.И. Разумовского Минздрава России;

Железнякова Наталия Александровна - кандидат медицинских наук, ассистент кафедры факультетской терапии лечебного факультета Саратовского ГМУ им. В.И. Разумовского Минздрава России;

Семенова Ольга Николаевна - ассистент кафедры факультетской терапии лечебного факультета Саратовского ГМУ им. В.И. Разумовского Минздрава России.

Рецензенты:
Чичкова М.А. - доктор медицинских наук, профессор, заведующая кафедрой кардиологии факультета последипломного образования, ФГБОУ ВПО «Астраханский государственный медицинский университет» Минздрава России;

Щёкотова А.П. -доктор медицинских наук, профессор, зав. кафедрой клинической лабораторной диагностики ФДПО, профессор кафедры факультетской терапии №1, ФГБОУ ВО «Пермский государственный медицинский университет имени академика Е.А. Вагнера» М3 России.

Тесты и задачи по кардиологии: учебное пособие / Е.А. Наумова, Т367 Ю.Г. Шварц, Н.А. Железнякова, О.Н. Семенова. - М.: Издательский дом Академии Естествознания, 2018. - 90 с.

\section{ISBN 978-5-91327-522-6 \\ DOI 10.17513/np.300}

В учебном пособии содержатся тестовые задания и задачи по основным разделам кардиологии. Учебное пособие предназначено для интернов и ординаторов, обучающихся по специальностям терапия и кардиология.

ISBN 978-5-91327-522-6

(C) Наумова Е.А., Шварц Ю.Г., Железнякова Н.А., Семенова О.Н., 2018

(C) Саратовский государственный медицинский университет, 2018

(c) ИД «Академия Естествознания»

(c) $\mathrm{AHO}$ «Академия Естествознания» 


\section{ОГЛАВЛЕНИЕ}

СПИСОК СОКРАЩЕНИЙ ...........................................................4

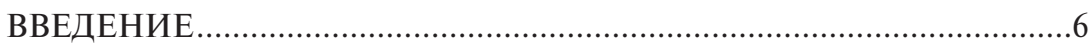

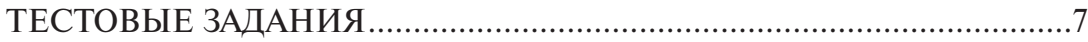

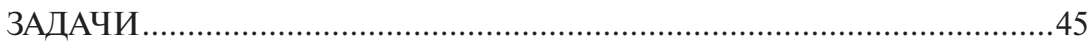

ЭТАЛОНЫ ОТВЕТОВ К ТЕСТОВЫМ ЗАДАНИЯМ ..........................82

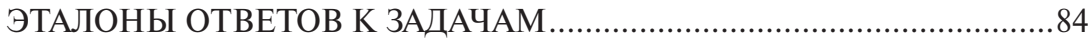

РЕКОМЕНДУЕМАЯ ЛИТЕРАТУРА ..................................................88 


\section{СПИСОК СОКРАЩЕНИЙ}

АГ - артериальная гипертония

АД - артериальное давление

АКШ - аорто-коронарное шунтирование

АМКР - антагонисты минералокортикоидных ркцепторов

АПФ - ангиотензинпревращающий фермент

БРА - блокатор рецепторов ангиотензина

БСМП - бригада скорой медицинской помощи

ГК - гипертонический криз

ДАД - диастолическое артериальное давление

ДЭхоКГ - допплерэхокардиография

иАПФ - ингибитор АПФ

ИБС - ишемическая болезнь сердца

ИМ - инфаркт миокарда

ИМТ - индекс массы тела

ЛЖ - левый желудочек

ЛП - левое предсердие

ЛПВП - липопротеиды высокой плотности

ЛПНП - липопротеиды низкой плотности

ЛПОНП - липопротеиды очень низкой плотности

МСКТ - мультиспиральная компьютерная томография

НМГ - низкомолекулярный гепарин

НПВС - нестероидные противовоспалительные средства

НФГ - нефракционированный гепарин

ОАМ - общий анализ мочи

OKC - острый коронарный синдром

ОМТ - оптимальная медикаментозная терапия

ОНМК - острое нарушение мозгового кровообращения

ОПН - острая почечная недостаточность

ПБЛНПГ - полная блокада левой ножки пучка Гиса

ПД - пульсовое давление

ПЖ - правый желудочек

ПП - правое предсердиеИТ

РААС - ренин-ангиотензин-альдостероновая система

САД - систолическое артериальное давление

СКЛ - срединно-ключичная линия 
СКФ - скорость клубочковой фильтрации

СОЭ - скорость оседания эритроцитов

ТАГ - триацилглицериды

ТИА - транзиторная ишемическая атака

ТЛБА - транслюминальная балонная ангиопластика

ТЭЛА - тромбоэмболия легочной артерии

УЗИ - ультразвуковое исследование

ФВ - фракция выброса

ФК - функциональный класс

ХБП - хроническая болезнь почки

ХПН - хроническая почечная недостаточность

ХСН - хроническая сердечная недостаточность

ЦОГ-1 - циклоксигеназа 1

ЦОГ-2 - циклоксигеназа 2

ЧКВ - чрескожные вмешательства

ЧСС - частота сердечных сокращений

ЭКГ - электрокардиография

ЭОС - электрическая ось сердца

BNP - натрийуретический пептид

NT-proBNP -

RW - реакция Вассермана

WPW - синдром Вольфа-Паркинсона-Уайта 


\section{ВВЕДЕНИЕ}

Современная кардиология на сегодняшний день представляет собой быстро развивающуюся область медицины, которая постоянно пополняется новыми данными. Это требует от обучающихся ознакомления с огромными объемами информации. Для усвоения массив знаний необходим адекватный тренинг и контроль.

Данное учебное пособие содержит тестовые задания и задачи по основным разделам кардиологии. Здесь отображены современные подходы к этиологии, патогенезу, клиническим проявлениям, принципам диагностика и терапии наиболее часто встречающейся кардиологической патологии. В данном учебном пособии акцентировано внимание на наиболее важных и в дальнейшем наиболее востребованных в практической деятельности аспектах лечения сердечно-сосудистых заболеваний.

Целью пособия является акцентировать внимание обучающихся на наиболее важных вопросах кардиологии. Из большого объема разрозненной информации использование тестовых заданий позволит вычленить и структурировать основные моменты, которые в дальнейшем могут быть использованы в практической медицине. Задачи, представленные в учебном пособии, помогут студентам объединить теоретические знания и попробовать их применить в конкретной клинической ситуации. 


\section{ТЕСТОВЫЕ ЗАДАНИЯ}

\section{Выберите один или несколько правильных ответов.}

1. ШКАЛА SСORЕ ИСПОЛЬЗУЕТСЯ ДЛЯ ОЦЕНКИ РИСКА СЕРДЕЧНО-СОСУДИСТЫХ ОСЛОЖНЕНИЙ У

1) пациентов с доказанным атеросклерозом любой локализации (коронарография, МСКТ и др, перенесенные ИМ, ТЛБА, АКШ, мозговой инсульт, периферический атеросклероз)

2) только пациентов с уровнем общего холестерина более 8 ммоль/л

3) пациентов с Сахарным диабетом II и I типа

4) пациентов, не имеющих в настоящее время отчетливых клинических проявлений сердечно-сосудистых заболеваний

5) всех пациентов с любыми сердечно-сосудистыми заболеваниями

2. К ГРУППЕ ОЧЕНЬ ВЫСОКОГО РИСКА СЕРДЕЧНО-СОСУДИСТЫХ ОСЛОЖНЕНИЙ ОТНОСЯТСЯ

1) пациенты с доказанным атеросклерозом любой локализации (коронарография, МСКТ и др, перенесенные ИМ, ТЛБА, АКШ, мозговой инсульт, периферический атеросклероз)

2) пациенты с уровнем общего холестерина более 8 ммоль/л

3) пациенты с Сахарным диабетом II и I типа при наличии микроальбуминурии

4) пациенты с ХБП (СКФ $<60$ мл/мин/1,732)

5) пациенты с артериальной гипертензией

6) пациенты с риском по шкале SCORE $\geq 10 \%$

3. К ГРУППЕ ВЫСОКОГО РИСКА СЕРДЕЧНО-СОСУДИСТЫХ ОСЛОЖНЕНИЙ ОТНОСЯТСЯ

1) пациенты, имеющие значительно повышенные уровни отдельных факторов риска (например гипертония высокой степени тяжести или семейная дислипидемия)

2) все пациенты с артериальной гипертензией

3) пациенты с уровнем общего холестерина более 8 ммоль/л

4) пациенты с сахарным диабетом II и I типа при наличии микроальбуминурии

5) пациенты с риском по шкале SCORE $\geq 5 \%$ и $<10 \%$ 


\section{4. ШКАЛА SCORE}

1) не заменяет знаний и клинического опыта врача

2) может использоваться для оценки риска сердечно-сосудистых осложнений у пациентов любого возраста

3) не учитывает, что реальный риск может превышать расчетный в некоторых ситуациях (например у пациентов с наследственной отягощенностью, ожирением, неблагоприятными социальными условиями)

4) используется для оценки сердечно-сосудистого риска у пациентов с перенесенным инфарктом миокарда

5) используется для оценки сердечно-сосудистого риска у пациентов с перенесенным ОНМК

5. ДЛЯ ОПРЕДЕЛЕНИЯ ЦЕЛЕВОГО УРОВНЯ ПРИ ЛЕЧЕНИИ ГИПЕРХОЛЕСТЕРИНЕМИИ ИСПОЛЬЗУЕТСЯ ТАКОЙ ПОКАЗАТЕЛЬ КАК
1) ЛПНП
2) ЛПОНП
3) ЛПВП
4) $\mathrm{TA} \Gamma$
5) индекс атерогенности

6. ЦЕЛЕВОЙ УРОВЕНЬ ЛПНП У ПАЦИЕНТОВ С ОЧЕНЬ ВЫСОКИМ РИСКОМ СЕРДЕЧНО-СОСУДИСТЫХ ОСЛОЖНЕНИЙ ПО ШКАЛЕ SCORE
1) $<1,5$ ммоль/л и/или $\geq 50 \%$ снижение от исходного уровня, когда целевой уровень не может быть достигнут
2) $<1,5$ ммоль/л
3) $<2$ ммоль $/ л$
4) $<2,5$ ммоль $/$ л
5) $<2,5$ ммоль/л и/или $\geq 50 \%$ снижение от исходного уровня, когда целевой уровень не может быть достигнут
6) $<3$ ммоль/л

7. ЦЕЛЕВОЙ УРОВЕНЬ ЛПНП У ПАЦИЕНТОВ С ВЫСОКИМ РИСКОМ СЕРДЕЧНО-СОСУДИСТЫХ ОСЛОЖНЕНИЙ ПО ШКАЛЕ SСORЕ

1) $<1,5$ ммоль/л и/или $\geq 50 \%$ снижение от исходного уровня, когда целевой уровень не может быть достигнут

2) $<1,5$ ммоль/л

3) $<2$ ммоль/л 
4) $<2,5$ ммоль/л

$5)<2,5$ ммоль/л и/или $\geq 50 \%$ снижение от исходного уровня, когда целевой уровень не может быть достигнут

6) $<3$ ммоль $/$ л

8. ЦЕЛЕВОЙ УРОВЕНЬ ЛПНП У ПАЦИЕНТОВ С УМЕРЕННЫМ РИСКОМ СЕРДЕЧНО-СОСУДИСТЫХ ОСЛОЖНЕНИЙ ПО ШКАЛЕ SСОRЕ

1) $<1,5$ ммоль/л и/или $\geq 50 \%$ снижение от исходного уровня, когда целевой уровень не может быть достигнут

2) $<1,5$ ммоль/л

3) $<2$ ммоль $/ л$

4) $<2,5$ ммоль $/$ л

$5)<2,5$ ммоль/л и/или $\geq 50 \%$ снижение от исходного уровня, когда целевой уровень не может быть достигнут

6) $<3$ ммоль $/$ л

9. ВТОРИЧНАЯ ГИПЕРХОЛЕСТЕРИНЕМИЯ РАЗВИВАЕТСЯ ПРИ СЛЕДУЮЩИХ ЗАБОЛЕВАНИЯХ

1) гипотиреоидизм

2) нефротический синдром

3) $\mathrm{OKC}$

4) синдром Кушинга

5) дилатационная кардиомиопатия

10. ДЛЯ ЛЕЧЕНИЯ ГИПЕРХОЛЕСТЕРИНЕМИИ ИСПОЛЬЗУЮТСЯ

1) статины

2) фибраты

3) иАПФ

4) никотиновая кислота

5) ингибиторы всасывания холестерина

6) n-3 жирные кислоты

11. ПРЕПАРАТЫ ПЕРВОГО РЯДА (ПРЕПАРАТЫ ВЫБОРА) ДЛЯ ЛЕЧЕНИЯ ГИПЕРХОЛЕСТЕРИНЕМИИ ЭТО

1) статины

2) фибраты

3) секвестранты жирных кислот

4) никотиновая кислота

5) ингибиторы всасывания холестерина

6) n-3 жирные кислоты 
12. КОМБИНИРОВАННАЯ ТЕРАПИЯ ГИПЕРХОЛЕСТЕРИНЕМИИ ВКЛЮЧАЕТ
1) статины + никотиновая кислота
2) статины + ингибиторы всасывания холестерина
3) статины + секвестранты жирных кислот
4) статины + аспирин
5) аспирин + клопидогрель

13. ЛЕКАРСТВЕННАЯ ТЕРАПИЯ ГИПЕРТРИГЛИЦИРЕДЕМИИ ПОКАЗАНА
1) при уровне ТАГ > 1,7 ммоль/л (> 150 мг/дл)
2) при уровне ТАГ > 2,3 ммоль/л (> 200 мг/дл)
3) при уровне ТАГ > 4,5 ммоль/л (> 400 мг/дл)
4) при любом уровне ТАГ
5) при уровне ЛПНП > 2,5 ммоль/л (100 мг/дл)

14. ДЛЯ ЛЕЧЕНИЯ ГИПЕРТРИГЛИЦЕРИДЕМИИ МОГУТ ИСПОЛЬЗОВАТЬСЯ
1) статины
2) фибраты
3) секвестранты жирных кислот
4) никотиновая кислота
5) ингибиторы всасывания холестерина
6) n-3 жирные кислоты

15. СРЕДСТВА ПЕРВОЙ ЛИНИИ ДЛЯ ТЕРАПИИ ГИПЕРТРИГЛИЦЕРИДЕМИИ
1) фибраты
2) статины
3) секвестранты жирных кислот
4) никотиновая кислота
5) ингибиторы всасывания холестерина
6) n-3 жирные кислоты

16. СТАРТОВАЯ ДОЗА АТОРВАСТАТИНА ДЛЯ ПАЦИЕНТОВ С ГИПЕРХОЛЕСТЕРИНЕМИЕЙ И ВЫСОКИМ РИСКОМ СЕРДЕЧНО-СОСУДИСТЫХ ОСЛОЖНЕНИЙ -
1) $10 \mathrm{M \Gamma}$
2) $20 \mathrm{M \Gamma}$
3) $40 \mathrm{MI}$ 

4) $80 \mathrm{M \Gamma}$
5) $100 \mathrm{M \Gamma}$

17. СТАРТОВАЯ ДОЗА АТОРВАСТАТИНА ДЛЯ ПАЦИЕНТОВ С ГИПЕРХОЛЕСТЕРИНЕМИЕЙ И ОЧЕНЬ ВЫСОКИМ РИСКОМ СЕРДЕЧНО-СОСУДИСТЫХ ОСЛОЖНЕНИЙ -
1) $10 \mathrm{M \Gamma}$
2) $20 \mathrm{M \Gamma}$
3) $40 \mathrm{M \Gamma}$
4) $80 \mathrm{M \Gamma}$
5) $100 \mathrm{M \Gamma}$

18. СТАРТОВАЯ ДОЗА АТОРВАСТАТИНА ДЛЯ ПАЦИЕНТОВ С ОКС
1) $10 \mathrm{M \Gamma}$
2) $20 \mathrm{M \Gamma}$
3) $40 \mathrm{M \Gamma}$
4) $80 \mathrm{Mr}$
5) $100 \mathrm{M \Gamma}$

19. СТАРТОВАЯ ДОЗА АТОРВАСТАТИНА ДЛЯ ПАЦИЕНТОВ СО СТАБИЛЬНОЙ ИБС И ИСХОДНО НИЗКИМ УРОВНЕМ ЛПНП (МЕНЕЕ 1,8 ммоль/л)
1) $10 \mathrm{M \Gamma}$
2) $20 \mathrm{M \Gamma}$
3) $40 \mathrm{M \Gamma}$
4) $80 \mathrm{M \Gamma}$
5) $100 \mathrm{M \Gamma}$

20. ДОЗУ ДЛЯ ДЛИТЕЛЬНОЙ ТЕРАПИИ СТАТИНАМИ ОПРЕДЕЛЯЮТ СЛЕДУЮЩИМ ОБРАЗОМ:

1) начинают со стартовой дозы (которая определяется в зависимости от заболевания и сердечно-сосудистого риска), а далее подбирается максимально переносимая доза статина

2) пациент остается на стартовой дозе и при проведении длительной терапии

3) начинают со стартовой дозы (которая определяется в зависимости от заболевания и сердечно-сосудистого риска), а далее необходимо добиться снижения уровня ЛПНП до целевого уровня, при необходимости, с использованием комбинированной терапии 
4) пациент принимает препарат в стартовой дозе 3 месяца, а далее терапия прекращается

5) пациент принимает препарат в стартовой дозе 3 месяца, а далее, при достижении целевого уровня ЛПНП терапия прекращается, при сохранении высоких значений ЛПНП - терапия продолжается

21. ОСНОВНЫЕ ПРИНЦИПЫ ВЕДЕНИЯ ПАЦИЕНТОВ С ПЕРИФЕРИЧЕСКИМ АТЕРОСКЛЕРОЗОМ ВКЛЮЧАЮТ
1) отказ от курения
2) снижение уровня ЛПНП оптимально до 1,8 ммоль/л (70 мг/дл) или на $50 \%$, если оптимальный уровень не может быть достигнут
3) оптимальное АД менее140/90 мм рт.ст.
4) антиагрегантная терапия всем пациентам
5) антиагрегантная терапия симптоматическим пациентам
6) контроль уровня HbAlс у пациентов с сахарным диабетом на уровне $6,5 \%$

22. ДЛЯ ПЕРВОНАЧАЛЬНОЙ ДИАГНОСТИКИ ПОРАЖЕНИЯ СОННЫХ АРТЕРИЙ РЕКОМЕНДОВАНО ИСПОЛЬЗОВАНИЕ
1) дуплексного исследования сосудов
2) ангиографии
3) компьютерной томографии
4) магнито-резонансной томографии
5) сцинтиграфии

23. РЕВАСКУЛЯРИЗАЦИЯ У ПАЦИЕНТОВ С АТЕРОСКЛЕРОЗОМ СОННЫХ АРТЕРИЙ БЕЗ ПЕРЕНЕСЕННЫХ ОНМК/ТИА ПОКАЗАНА В СЛУЧАЕ
1) стеноза $>30 \%$
2) стеноза $<60 \%$
3) стеноза $60-99 \%$
4) стеноза 60-99\% и ожидаемой продолжительности жиз- ни $>5$ лет и подходящей анатомией сонных артерий
5) полной окклюзии сонной артерии

24. РЕВАСКУЛЯРИЗАЦИЯ У ПАЦИЕНТОВ С АТЕРОСКЛЕРОЗОМ СОННЫХ АРТЕРИЙ И ПЕРЕНЕСЕННЫМИ ОНМК/ТИА ПОКАЗАНА В СЛУЧАЕ
1) стеноза $<50 \%$
2) стеноза $>60 \%$ 


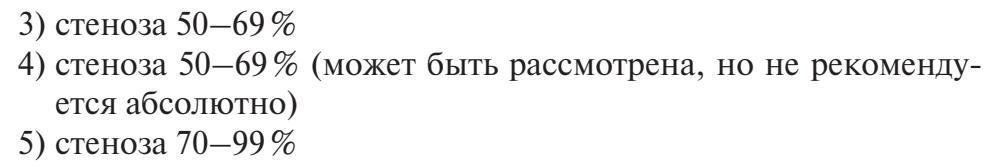

25. ОПТИМАЛЬНАЯ ЛЕКАРСТВЕННАЯ ТЕРАПИЯ ПАЦИЕНТОВ С БЕССИМПТОМНЫМ АТЕРОСКЛЕРОЗОМ СОННЫХ АРТЕРИЙ ВКЛЮЧАЕТ
1) антиагреганты
2) антикоагулянты
3) статины
4) бета-блокаторы
5) все вышеперечисленное

26. ОПТИМАЛЬНАЯ ЛЕКАРСТВЕННАЯ ТЕРАПИЯ ПАЦИЕНТОВ С АТЕРОСКЛЕРОЗОМ СОННЫХ АРТЕРИЙ, ПЕРЕНЕСШИХ ОНМК/ТИА ВКЛЮЧАЕТ
1) антиагреганты
2) антикоагулянты
3) статины
4) бета-блокаторы
5) все вышеперечисленное
6) $\mathrm{a}+\mathrm{c}$

27. ДВОЙНАЯ АНТИАГРЕГАНТНАЯ ТЕРАПИЯ (АСПИРИН + КЛОПИДОГРЕЛЬ) ПОКАЗАНА

1) всем пациентам с атеросклерозом каротидных артерий

2) пациентам с атеросклерозом сонных артерий, перенесшим ОНМК/ТИА

3) только во время процедуры стентирования сонной артерии

4) все вышеперечисленное

28. РАЗВИТИЕ СТАБИЛЬНЫХ ФОРМ ИШЕМИЧЕСКОЙ БОЛЕЗНИ СЕРДЦА СВЯЗАНО

1) с атеромой в коронарной артерии, в покрышке которой имеется трещина, «прикрытая» тромбом, состоящим из тромбоцитов, фибрина, эритроцитов

2) с атеромой в коронарной артерии, в покрышке которой имеется разрыв, «прикрытый» тромбом, состоящим из тромбоцитов, фибрина, эритроцитов 
3) с увеличившейся атеромой в коронарной артерии, постепенно суживающей просвет сосуда, покрышка которой и монослой эндотелия, покрывающего атеросклеротическую бляшку сохранены

4) с появлением на поверхности атеромы в коронарной артерии тромба, размеры которого могут то увеличиваться, то уменьшаться

5) с появлением на поверхности атеромы в коронарной артерии тромба, полностью окклюзирующего сосуд

29. К СТАБИЛЬНЫМ ФОРМАМ ИБС ОТНОСИТСЯ
1) нестабильная стенокардия
2) стенокардия напряжения любого функционального класса
3) стенокардия напряжения I-III функционального класса
4) ишемическая кардиомиопатия
5) перенесенный инфаркт миокарда
6) ранняя постинфарктная стенокардия

30. СИНДРОМ СТЕНОКАРДИИ ЧАЩЕ ВСЕГО ВСТРЕЧАЕТСЯ
1) при митральном стенозе
2) при митральной недостаточности
3) при стенозе устья легочной артерии
4) при стенозе устья аорты
5) при недостаточности аортального клапана

\section{1. К НЕСТАБИЛЬНЫМ ФОРМАМ ИБС ОТНОСЯТСЯ}
1) нестабильная стенокардия
2) инфаркт миокарда
3) внезапная кардиальная смерть
4) стенокардия напряжения IV функционального класса
5) перенесенный инфаркт миокарда
6) ранняя постинфарктная стенокардия

32. РЕКОМЕНДОВАННЫЕ ДОЗЫ АЦЕТИЛСАЛИЦИЛОВОЙ КИСЛОТЫ ДЛЯ ПАЦИЕНТОВ СО СТАБИЛЬНЫМИ ФОРМАМИ ИБС ЭТО
1) $75 \mathrm{мг/сутки}$
2) $75-150$ мг/сутки
3) $75-325$ мг/сутки
4) $150-325$ мг/сутки
5) $125-150$ мг/сутки 
33. ДЛИТЕЛЬНОСТЬ ТЕРАПИИ АЦЕТИЛСАЛИЦИЛОВОЙ КИСЛОТОЙ У ПАЦИЕНТОВ С СТАБИЛЬНЫМИ ФОРМАМИ ИБС СОСТАВЛЯЕТ
1) 1 месяц
2) 6 месяцев
3) 12 месяцев
4) 2 года
5) до 5 лет
6) пожизненно (при отсутствии противопоказаний и побочных эфектов)

34. ДВОЙНАЯ АНТИАГРЕГАНТНАЯ ТЕРАПИЯ ПОКАЗАНА

1) всем пациентам со стабильными формами ИБС

2) всем пациентам с нестабильными формами ИБС

3) всем пациентам с клинически выраженным периферическим атеросклерозом

4) пациентам после перенесенного ОНМК

5) пациентам после ЧКВ

35. АЦЕТИЛСАЛИЦИЛОВАЯ КИСЛОТА БЛОКИРУЕТ РЕЦЕПТОРЫ ТРОМБОЦИТОВ
1) ЦОГ-1 и ЦОГ-2
2) только ЦОГ-1
3) $\mathrm{P} 2 \mathrm{Y} 12$
4) фосфодиэстеразу
5) IIbIIIa

36. КЛОПИДОГРЕЛЬ БЛОКИРУЕТ РЕЦЕПТОРЫ ТРОМБОЦИТОВ

1) ЦОГ-1 и ЦОГ-2

2) только ЦОГ-1

3) $\mathrm{P} 2 \mathrm{Y} 12$

4) фосфодиэстеразу

5) IIbIIIa

37. ИЗ ВСЕХ БЛОКАТОРОВ Р2Ү12 РЕЦЕПТОРОВ, НЕ ЯВЛЯЕТСЯ ПРО-ЛЕКАРСТВОМ, А ЯВЛЯЕТСЯ АКТИВНЫМ ВЕЩЕСТВОМ ТОЛЬКО

1) клопидогрель

2) прасугрель

3) тикагрелор 
38. СРЕДИ ПАЦИЕНТОВ СО СТАБИЛЬНЫМИ ФОРМАМИ ИБС ТЕРАПИЯ НЕПРЯМЫМИ АНТИКОАГУЛЯНТАМИ ПОКАЗАНА

1) пациентам с фибрилляцией предсердий, после оценки индивидуального риска тромбо-эмболических осложнений

2) пациентам с протезированными клапанами сердца

3) пациентам после ОИМ, при непереносимости антиагрегантов

4) пациентам с тромбами в полостях сердца

5) пациентам с вазоспастической стенокардией

39. АНТИАНГИНАЛЬНЫЕ ПРЕПАРАТЫ ПЕРВОЙ ЛИНИИ ЭТО
1) бета-блокаторы
2) антагонисты кальция
3) ивабрадин
4) длительно-действующие нитраты
5) никорандил
6) ранолазин
7) триметазидин

40. АНТИАНГИНАЛЬНЫЕ ПРЕПАРАТЫ ВТОРОЙ ЛИНИИ ЭТО
1) бета-блокаторы
2) антагонисты кальция
3) ивабрадин
4) длительно-действующие нитраты
5) никорандил
6) ранолазин
7) триметазидин

41. ПРЕПАРАТЫ, ВЛИЯЮЩИЕ НА ПРОГНОЗ (ВЫЖИВАЕМОСТЬ) ПАЦИЕНТОВ, ИМЕЮЩИХ ТОЛЬКО СТАБИЛЬНУЮ СТЕНОКАРДИЮ НАПРЯЖЕНИЯ (И НЕ ИМЕЮЩИХ ПЕРЕНЕСЕННОГО ИНФАРКТА МИОКАРДА, ДИАБЕТА, СЕРДЕЧНОЙ НЕДОСТАТОЧНОСТИ)
1) бета-блокаторы
2) аспирин
3) клопидогрель
4) ингибиторы АПФ
5) антагонисты кальция
6) статины 
42. ОПТИМАЛЬНАЯ МЕДИКАМЕНТОЗНАЯ ТЕРАПИЯ ПАЦИЕНТОВ СО СТАБИЛЬНОЙ СТЕНОКАРДИЕЙ НАПРЯЖЕНИЯ ВКЛЮЧАЕТ

1) аспирин

2) статины

3) антиишемические препараты

4) иАПФ

5) иАПФ только у пациентов с гипертонией, диабетом сердечной недостаточностью

\section{3. ВЫПОЛНЕНИЕ АНГИОГРАФИИ РЕКОМЕНДОВАНО}

1) пациентам с подтвержденной неинвазивными тестами стабильной стенокардией напряжения III ФК (особенно без адекватного ответа на ОМТ)

2) пациентам с подтвержденной неинвазивными тестами стенокардией напряжения и высоким риском сердечно-сосудистых осложнений(особенно без адекватного ответа на ОМТ)

3) бессимптомным пациентам или у пациентам с симптомами стенокардии легкой и умеренной степени тяжести на фоне OMT, у которых при неинвазивных тестах выявлены признаки высокого риска сердечно-сосудистых осложнений

4) пациентам с симптомами стенокардии, у которых неинвазивные тесты показали противоречивые результаты

5) всем пациентам со стабильной стенокардией напряжения

44. ИНФАРКТ МИОКАРДА ЭТО

1) некроз миокарда вследствие длительной острой ишемии.

2) некроз миокарда вследствие длительной острой ишемии из-за окклюзии коронарной артерии тромбом

3) некроз миокарда любой этиологии

4) некроз миокарда, подтвержденный повышением уровня кардиоспецифических ферментов.

5) все вышеперечисленное

45. УНИВЕРСАЛЬНАЯ КЛАССИФИКАЦИЯ ИНФАРКТА МИОКАРДА ВКЛЮЧАЕТ СЛЕДУЮЩИЕ ЕГО ТИПЫ

1) спонтанный инфаркт миокарда (тип I)

2) инфаркт миокарда вследствии ишемического дисбаланса (тип II)

3) ИМ, приведший к смерти, когда определение биомаркеров невозможно (тип III)

4) ИМ, связанный с ЧКВ (тип IVa) 
5) ИМ, связанный с тромбозом стента (тип IVб)

6) ИМ, ассоциированный с АКШ (тип V)

7) ИМ, связанный с острой респираторной вирусной инфекцией (тип VI)

46. СОГЛАСНО ТРЕТЬЕМУ УНИВЕРСАЛЬНОМУ ОПРЕДЕЛЕНИЮ ИНФАРКТА МИОКАРДА, КРИТЕРИЯМИ ДИАГНОСТИКИ ИНФАРКТА МИОКАРДА ПЕРВОГО ТИПА ЯВЛЯЮТСЯ:

1) наличие симптомов ишемии и/или изменений на ЭКГ и/или повышения и/или закономерной динамики снижения кардиоспецифических ферментов (необходимо наличие 2 любых критериев из 3-х)

2) повышение и/или закономерная динамика снижения кардиоспецифических ферментов в сочетании с симптомами имшемии и/или изменениями на ЭКГ и/или поялением зон гипо/ акинезии и/или выявлением интракоронарного тромба (при ангиографии или аутопсии).

3) наличие симптомов ишемии в сочетании с повышением и/ или закономерной динамикой снижения кардиоспецифических ферментов и/или изменениями на ЭКГ и/или поялением зон гипо/акинезии и/или выявлением интракоронарного тромба (при ангиографии или аутопсии).

4) повышение кардиоспецифических ферментов, и этого достаточно

5) клиника инфаркта миокарда и изменения на ЭКГ

47. ОСТРЫЙ КОРОНАРНЫЙ СИНДРОМ ВКЛЮЧАЕТ В СЕБЯ СЛЕДУЮЩИЕ ФОРМЫ ИБС

1) нестабильная стенокардия

2) инфаркт миокарда

3) внезапная кардиальная смерть

4) стенокардия напряжения I-III функционального класса

5) перенесенный инфаркт миокарда

6) ранняя постинфарктная стенокардия

48. НЕСТАБИЛЬНАЯ СТЕНОКАРДИЯ ПРОГНОСТИЧЕСКИ НЕБЛАГОПРИЯТНА В ОТНОШЕНИИ

1) развития инфаркта миокарда

2) развития синдрома Дресслера

3) развития фатальных нарушений ритма сердца 
4) развития легочной гипертензии

5) развития венозной недостаточности

49. НЕСТАБИЛЬНАЯ СТЕНОКАРДИЯ IА КЛАССА ПО ВRAUNWALD ЭТО

1) прогрессирующая стенокардия напряжения

2) стенокардия покоя в последние 48 часов

3) стенокардия покоя, но не в последние 48 часов

4) стенокардия развивающаяся без видимой причины

5) стенокардия развивающаяся на фоне экстракардиальных причин

6) ранняя постинфарктная стенокардия

50. НЕСТАБИЛЬНАЯ СТЕНОКАРДИЯ ІІІВ КЛАССА ПО BRAUNWALD ЭTO

1) прогрессирующая стенокардия

2) стенокардия покоя в последние 48 часов

3) стенокардия покоя, но не в последние 48 часов

4) стенокардия развивающаяся без видимой причины

5) стенокардия развивающаяся на фоне экстракардиальных причин

6) ранняя постинфарктная стенокардия

51. К ВОЗМОЖНЫМ НЕКОРОНАРОГЕННЫМ ПРИЧИНАМ ПОВЫШЕНИЯ ТРОПОНИНОВ ОТНОСЯТСЯ

1) хроническая и острая почечная дисфункция

2) тахи- или брадиаритмии

3) ТЭЛА

4) инсульт

5) миокардит

6) критическое состояние пациента (напрмер сепсис)

\section{2. ТРАНСТОРАКАЛЬНАЯ ДЭХОКГ ПОЗВОЛЯЕТ}

1) оценить локальную сократимость миокарда и в ряде случаев выявить зоны гипо- и/или акинезии

2) дифференцировать острый инфаркт миокарда и длительно существующий рубец миокарда

3) однозначно подтвердить или исключить наличие некроза миокарда

4) оценить глобальную сократимость миокарда

5) исключить наличие тромбов в полостях сердца 
53. МУЛЬТИСПИРАЛЬНАЯ КОМПЬЮТЕРНАЯ АНГИОГРАФИЯ ИСПОЛЬЗУЕТСЯ ДЛЯ
1) визуализации коронарных артерий
2) диагностики ишемии миокарда
3) диагностики некроза миокарда
4) визуализации полостей сердца
5) визуализации клапанного аппарата

54. К РАННИМ ОСЛОЖНЕНИЯМ ОСТРОГО ИНФАРКТА МИОКАРДА ОТНОСЯТСЯ
1) отек легких
2) остановка кровообращения
3) разрыв миокарда
4) синдром Дресслера
5) хроническая аневризма левого желудочка

55. ЭФФЕКТИВНЫМ ТРОМБОЛИЗИС СЧИТАЕТСЯ В СЛУЧАЕ

1) уменьшение АЧТВ

2) формирования зубца Q в двух последовательных отведениях

3 ) снижения уровня КФК через 3 часа после введения препарата

4) снижения сегмента ST более чем на $50 \%$ через 3 часа после введения препарата

5) увеличения АЧТВ в 2 раза

56. ПОТЕНЦИАЛЬНЫЕ ПРЕИМУЩЕСТВА НМГ ПЕРЕД НФГ

1) подкожное применение - 1-2 раза в день

2) нет необходимости в лабораторном контроле

3) меньшее связывание с белками плазмы и клетками эндотелия

4) более предсказуемая степень антикоагуляции

5) реже тромбоцитопения

6) отсутствие влияния на пуриновый обмен

57. ПРИ ВНУТРИВЕННОМ ПРИМЕНЕНИИ ГЕПАРИНА КОНТРОЛЬ ЛЕЧЕНИЯ ПРОВОДИТСЯ ПУТЕМ ОПРЕДЕЛЕНИЯ АЧТВ, КОТОРОЕ К КОНЦУ ПЕРВЫХ СУТОК ДОЛЖНО БЫТЬ УВЕЛИЧЕНО
1) $2,5-3,5$ раза
2) $1,5-2,5$ раза
3) $3,5-4,5$ раза
4) $0,5-1,2$ раза 
58. ЭКГ-ПРИЗНАКИ ОСТРОГО ИНФАРКТА МИОКАРДА (ПРИ ОТСУТСТВИИ ГИПЕРТРОФИИ МИОКАРДА ЛЕВОГО ЖЕЛУДОЧКА И ПБЛНПГ) ЯВЛЯЮТСЯ

1) признаки AV-блокады II степени

2) элевация сегмента ST в двух последовательных отведениях

3) наличие признаков ФП

4) депрессия сегмента ST в двух последовательных отведениях и/или инверсия зубца Т в двух последовательных отведениях

5) наличие частой желудочковой экстрасистолии

59. ТЕРМИН «РЕЦИДИВ» ИНФАРКТА МИОКАРДА ПРИМЕНЯЕТСЯ В СЛУЧАЕ ЕСЛИ

1) острый инфаркт миокарда развивается после 28 дней, прошедших с момента первого инфаркта миокарда

2) острый инфаркт миокарда развивается в течение 28 дней, прошедших с момента первого инфаркта миокарда

3) острый инфаркт миокарда развивается после 45 дней, прошедших с момента первого инфаркта миокарда

4) острый инфаркт миокарда развивается после 2 месяцев, прошедших с момента первого инфаркта миокарда

60. ДЛЯ ОЦЕНКИ РИСКА ИШЕМИЧЕСКИХ ИСХОДОВ В БЛИЖАЙШИЕ И СРЕДНИЕ СРОКИ ПРИ ОКС БЕЗ ПОДЪЕМА СЕГМЕНТА SТ ИСПОЛЬЗУЕТСЯ ИНДЕКС
1) SCORE
2) CRUSADE
3) GRACE
4) CHADS2
5) HAS-BLED

61. ДЛЯ ОЦЕНКИ РИСКА КРОВОТЕЧЕНИЙ ПРИ ОКС БЕЗ ПОДЬЕМА СЕГМЕНТА ЛТ ИСПОЛЬЗУЕТСЯ ИНДЕКС
1) SCORE
2) CRUSADE
3) GRACE
4) CHADS2
5) HAS-BLED

62. У ПАЦИЕНТОВ С ОКС БЕЗ ПОДЬЕМА СЕГМЕНТА SТ НАЗНАЧЕНИЕ НИТРАТОВ ПОКАЗАНО

1) пациентам с установленным диагнозом инфаркт миокарда

2) при рецидивирующей стенокардии (внутривенно) 
3) у пациентов с острой сердечной недостаточностью (внутривенно)

4) всем пациентам без исключения

5) для купирования стенокардии (перорально или внутривенно)

63. ВЫБЕРИТЕ ИЗ ПЕРЕЧИСЛЕННОГО АНТИАНГИНАЛЬНЫЕ ПРЕПАРАТЫ, РЕКОМЕНДОВАННЫЕ ДЛЯ ТЕРАПИИ ОКС БЕЗ ПОДЬЕМА СЕГМЕНТА SТ
1) триметазидин
2) антагонисты кальция
3) ивабрадин
4) никорандил
5) ранолазин
6) бета-блокаторы

64. НАГРУЗОЧНАЯ ДОЗА АСПИРИНА У ПАЦИЕНТОВ С ОКС БЕЗ ПОДЬЕМА СЕГМЕНТА SТ
1) $75-100 \mathrm{M \Gamma}$
2) $150-300 \mathrm{Mг}$
3) $500 \mathrm{M \Gamma}$
4) вообще не используется

65. КАКИЕ ПРЕПАРАТЫ ИЗ ПЕРЕЧИСЛЕННЫХ ОТНОСЯТСЯ К БЛОКАТОРАМ Р2Ү12 РЕЦЕПТОРОВ
1) апиксабан
2) аспирин
3) клопидогрель
4) прасугрель
5) тикагрелор
6) дабигатран

\section{6. ДВОЙНАЯ АНТИАГРЕГАНТНАЯ ТЕРАПИЯ ПОКАЗАНА}

1) всем пациентам с ОКС без подъема сегмента ST (при отсутствии противопоказаний) пожизненно

2) пациентам с ОKC без подъема сегмента ST, имеющим высокий риск осложнений (при отсутствии противопоказаний) пожизненно

3) всем пациентам с ОКС без подъема сегмента ST (при отсутствии противопоказаний) на протяжении 12 месяцев

4) пациентам с OKC без подъема сегмента ST, имеющим высокий риск осложнений (при отсутствии противопоказаний) на протяжении 12 месяцев 
67. У ПАЦИЕНТОВ С ОКС БЕЗ ПОДЬЕМА СЕГМЕНТА ST

1) для двойной антиагрегантной терапии допустимо использование любого из блокаторов Р2Y12 рецепторов

2) для двойной антиагрегантной терапии Клопидогрель является препаратом выбора

3) для двойной антиагрегантной терапии Клопидогрель рекомендуется назначать пациентам, которые не могут принимать прасугрель или тикагрелор

4) двойная антиагрегангтная терапия рекомендуется на протяжении 12 месяцев

5) двойная антиагрегантная терапия должна включать аспирин и блокатор Р2Y12 рецепторов

68. АНТИКОАГУЛЯНТЫ, РЕКОМЕНДОВАННЫЕ ДЛЯ ТЕРАПИИ ОКС БЕЗ ПОДЬЕМА СЕГМЕНТА ST
1) нефракционированный гепарин внутривенно
2) эноксапарин
3) фондапаринукс
4) бивалирудин
5) апиксабан
6) дабигатран

69. У ПАЦИЕНТОВ С ОКС ПРИ НЕОБХОДИМОСТИ ПЕРЕХОД С НФГ НА НМГ, И НАОБОРОТ

1) рекомендован

2) не рекомендован

70. ИНВАЗИВНАЯ СТРАТЕГИЯ (АНГИОГРАФИЯ И ЧКВ) ПАЦИЕНТАМ С ОКС БЕЗ ПОДЪЕМА СЕГМЕНТА SТ В ПЕРВЫЕ 2 ЧАСА (Т.Е. ЭКСТРЕННО) ПОКАЗАНА

1) пациентам с рефрактерной или рецидивирующей стенокардией

2) пациентам с изменениями на ЭКГ (несмотря на интенсивную антиангинальную терапию)

3) пациентам с острой сердечной недостаточностью или нестабильной гемодинамикой

4) пациентам с умеренным и высоким риском по шкале GRACE $>140$

5) пациентам с повышением уровня тропонинов

6) пациентам с почечной недостаточностью 
71. ИНВАЗИВНАЯ СТРАТЕГИЯ (АНГИОГРАФИЯ И ЧКВ) ПАЦИЕНТАМ С ОКС БЕЗ ПОДЬЕМА СЕГМЕНТА SТ В ПЕРВЫЕ 24 ЧАСА (Т.Е. РАННЕЕ ИНВАЗИВНОЕ ЛЕЧЕНИЕ) ПОКАЗАНА

1) пациентам с рефрактерной или рецидивирующей стенокардией

2) пациентам с изменениями на ЭКГ (несмотря на интенсивную антиангинальную терапию)

3) пациентам с острой сердечной недостаточностью или нестабильной гемодинамикой

4) пациентам с повышением уровня тропонинов

5) пациентам с ранней постинфарктной стенокардией

6) пациентам с риском по шкале GRACE > 140

\section{2. РАЗВИТИЕ ИНФАРКТА МИОКАРДА 1 ТИПА СВЯЗАНО С}

1) спонтанным разрывом атеросклеротической бляшки с последующим развитием интракоронарного тромба только на фоне ИБС.

2) спонтанным разрывом атеросклеротической бляшки с последующим развитием интракоронарного тромба как на фоне ИБС, так и в редких случаях на фоне непораженных коронарных артерий.

3) развитием интракоронарного тромба и последующим повреждением миокарда после процедуры ЧКВ.

4) развитием тромбоза в стентированной артерии

5) развитием острой ишемии на фоне высокой потребности миокарда в кислороде при бради- и/или тахиаритмии

73. ВНЕЗАПНАЯ СЕРДЕЧНАЯ СМЕРТЬ, ОБУСЛОВЛЕННАЯ ИНФАРКТОМ МИОКАРДА (ИНФАРКТ МИОКАРДА 3 ТИПА) ДИАГНОСЦИРУЕТСЯ

1) у всех пациентов, умерших без свидетелей, независимо от анамнеза заболевания

2) у всех пациентов, умерших внезапно от симптомов, схожих с ишемией, и/или имеющих изменения на ЭКГ, характерные для ишемии, независимо от наличия/отсутствия данных об изменениях биомаркеров некроза

3) у всех пациентов с анамнезом ИБС, умерших внезапно, без свидетелей

4) у всех пациентов, умерших в послеоперационном периоде после ЧКВ

5) у всех пациентов, умерших в послеоперационном периоде после АКШ 
74. КАКОЙ АНАЛЬГЕТИК ЯВЛЯЕТСЯ ПРЕПАРАТОМ ВЫБОРА ДЛЯ ОБЕЗБОЛИВАНИЯ ПАЦИЕНТОВ С ОКС С ПОДЬЕМОМ СЕГМЕНТА ST
1) промедол
2) морфин
3) анальгин с димедролом
4) кеторол
5) любой доступный препарат из группы НПВС

75. ЭКСТРЕННОЕ ВОСТАНОВЛЕНИЕ КОРОНАРНОГО КРОВОТОКА ПОКАЗАНО

1) всем пациентам с ОKC

2) всем пациентам с ОКС с подъемом сегмента ST

3) пациентам с ОKС с подъемом сегмента ST, имеющим рецидивирующие ангинальные приступы и/или острую левожелудочковую недостаточность

4) всем пациентам с ОКС без подъема сегмента ST

5) пациентам с OKC без подъема сегмента ST, имеющим рецидивирующие ангинальные приступы и/или острую левожелудочковую недостаточность

76. ЭКСТРЕННОЕ ВОСТАНОВЛЕНИЕ КОРОНАРНОГО КРОВОТОКА ВОЗМОЖНО СЛЕДУЮЩИМИ МЕТОДАМИ

1) тромболизисом у всех пациентов с ОКС

2) тромболизисом только у пациентов с ОКС с подъемом сегмента ST

3) ЧКВ у всех пациентов с ОКС с подъемом сегмента ST

4) ЧКВ у всех пациентов с ОКС без подъема сегмента ST

5) ЧКВ у пациентов с ОКС без подъема сегмента ST, имеющим рецидивирующие ангинальные приступы и/или острую левожелудочковую недостаточность

6) ЧКВ у пациентов с ОКС без подъема сегмента ST, имеющим факторы высокого риска осложнений (изменения на ЭКГ, повышение тропонинов и т.д.)

77. ЦЕЛЬ ПРИ ОРГАНИЗАЦИИ ОКАЗАНИЯ ПОМОЩИ ПАЦИЕНТАМ С ОКС С ПОДЬЕМОМ СЕГМЕНТА SТ - ЭТО ВОССТАНОВЛЕНИЕ КОРОНАРНОГО КРОВОТОКА

1) в первые 120 минут после появления симптомов ищемии

2) в первые 6 часов после появления симптомов ищемии

3) в первые 12 часов после появления симптомов ищемии 
4) в первые 24 часа после появления симптомов ищемии

5) в первые 24 часа после появления симптомов ищемии

78. У ПАЦИЕНТОВ С ОКС С ПОДЬЕМОМ СЕГМЕНТА SТ В ПЕРВЫЕ 120 МИНУТ ПОСЛЕ ПОЯВЛЕНИЯ СИМПТОМОВ ИШЕМИИ НАИБОЛЕЕ ПРЕДПОДЧТИТЕЛЬНОЙ ТАКТИКОЙ ЯВЛЯЕТСЯ
1) восстановление коронарного кровотока путем гепаринотерапии
2) восстановление коронарного кровотока путем тромболизиса
3) восстановление коронарного кровотока путем ЧКВ
4) восстановление коронарного кровотока путем АКШ
5) восстановление коронарного кровотока любым возможным способом

79. ПАЦИЕНТАМ С ОКС С ПОДЬЕМОМ СЕГМЕНТА SТ НАГРУЗОЧНАЯ ДОЗА АСПИРИНА
1) назначается всегда (при отсутствии противопоказаний)
2) составляет 300 мг для всех пациентов
3) составляет 500 мг для всех пациентов
4) составляет 150-300 мг per os. или 80-150 мг внутривенно (если per os невозможно) для пациентов, которым экстренно первично будет выполняться ЧКВ
5) составляет 150-500 мг per os. или 350 мг внутривенно (если per os невозможно) для пациентов, которым экстренно будет выполняться тромболизис

80. АНТИКОАГУЛЯНТЫ, РЕКОМЕНДОВАННЫЕ ДЛЯ ИСПОЛЬЗОВАНИЯ У ПАЦИЕНТОВ С ОКС С ПОДЬЕМОМ СЕГМЕНТА SТ, У КОТОРЫХ ПЕРВИЧНОЙ ТАКТИКОЙ ЯВЛЯЕТСЯ ВЫПОЛНЕНИЕ ЧКВ
1) нефракционированный гепарин в/в
2) нефракционированный гепарин п/к
3) ривароксабан
4) эноксапарин
5) фондапаринукс
6) бивалирудин

81. АНТИКОАГУЛЯНТЫ, РЕКОМЕНДОВАННЫЕ ДЛЯ ИСПОЛЬЗОВАНИЯ У ПАЦИЕНТОВ С ОКС С ПОДЬЕМОМ СЕГМЕНТА SТ, У КОТОРЫХ ПЕРВИЧНОЙ ТАКТИКОЙ ЯВЛЯЕТСЯ ВЫПОЛНЕНИЕ ТРОМБОЛИЗИСА

1) нефракционированный гепарин в/в

2) нефракционированный гепарин п/к 

3) ривароксабан
4) эноксапарин
5) фондапаринукс
6) бивалирудин

82. У ПАЦИЕНТОВ С ОКС С ПОДЬЕМОМ СЕГМЕНТА SТ ПРИМЕНЕНИЕ НИТРАТОВ ПОКАЗАНО

1) перорально у всех пациентов

2) перорально у всех пациентов с сохраняющимися болевыми проявлениями острой ишемии

3) у пациентов с острой сердечной недостаточностью (внутривенно)

4) у пациентов с гипертонией (внутривенно)

5) у пациентов с сохраняющимися болевыми проявлениями острой ишемии (внутривенно)

83. АНТИАНГИНАЛЬНЫЕ ПРЕПАРАТЫ, РЕКОМЕНДОВАННЫЕ ДЛЯ ТЕРАПИИ ОКС С ПОДЬЕМОМ СЕГМЕНТА ЭТО
1) бета-блокаторы
2) антагонисты кальция
3) авабрадин
4) никорандил
5) ранолазин
6) триметазидин

84. ПРИ ОКС С ПОДЬЕМОМ СЕГМЕНТА ТТ ИАПФ ДОЛЖНЫ БЫТЬ НАЗНАЧЕНЫ

1) всем пациентам в первые 24 часа

2) в первые 24 часа всем пациентам с ОКС с подъемом сегмента ST и с признаками сердечной недостаточности, систолической дисфункцией ЛЖ, диабетом, или передним инфарктом

3) в первые 24 часа всем пациентам с ОКС с подъемом сегмента ST и с признаками кардиогенного шока

4) в первые 24 часа всем пациентам с ОКС с подъемом сегмента ST и с непереносимостью бета-блокаторов

5) в первые 24 часа всем пациентам с ОКС с подъемом сегмента ST и с непереносимостью БРА

85. ПРИ НЕПЕРЕНОСИМОСТИ ИАПФ ПАЦИЕНТАМИ С ОКС С ПОДЬЕМОМ СЕГМЕНТА ЯТ ПРЕПАРТОМ ВЫБОРА ЯВЛЯЕТСЯ

1) лозартан

2) вальсартан 

3) телмисартан
4) ирбесартан
5) кандесартан

86. К ТРОМБОЛИТИКАМ ОТНОСЯТСЯ СЛЕДУЮЩИЕ ПРЕПАРАТЫ
1) апиксабан
2) стрептокиназа
3) альтеплаза
4) ретеплаза
5) ренектеплаза
6) дабигатран

87. АБСОЛЮТНЫЕ ПРОТИВОПОКАЗАНИЯ К ТРОМБОЛИЗИСУ ЭТО

1) геморрагический инсульт любого срока давности

2) инсульт неизвестного характера любого срока давности

3) ЧМТ/другая травма/операционные вмешательства в последние 3 месяца

4) ЧМТ/другая травма/операционные вмешательства в последние 3 недели

5) желудочно-кишечное кровотечение в анамнезе

6) желудочно-кишечное кровотечение в последний месяц

88. ОТНОСИТЕЛЬНЫЕ ПРОТИВОПОКАЗАНИЯ К ТРОМБОЛИЗИСУ ЭТО

1) ТИА в последние 6 месяцев

2) ЧМТ/другая травма/операционные вмешательства в последние 3 месяца

3) желудочно-кишечное кровотечение в анамнезе

4) терапия оральными антикоагулянтами

5) беременность

6) устойчивая гипертония (СД > 180 мм и/или ДД > 110 мм)

89. В ПЕРВЫЕ 24 ЧАСА ОТ РАЗВИТИЯ ОКС С ПОДЬЕМОМ СЕГМЕНТА SТ ПОСЛЕ ВЫПОЛНЕНИЯ ПЕРВИЧНОГО ТРОМБОЛИЗИСА АНГИОГРАФИЯ (С ВОЗМОЖНЫМ ЧКВ)

1) показана всем пациентам

2) показана только пациентам без признаков восстановления коронарного кровотока после тромболизиса

3) противопоказана всем пациентам

4) противопоказана пациентам с признаками восстановления коронарного кровотока 
5) показана только пациентам с сохраняющимися проявлениями ОКС

90. С УЧЕТОМ ТЕЧЕНИЯ И ДЛИТЕЛЬНОСТИ ФП ВЫДЕЛЯЮТ СЛЕДУЮЩИЕ ЕЁ ТИПЫ

1) впервые выявленная

2) пароксизмальная

3) персистирующая

4) длительная персистирующая

5) постоянная

6) повторно выявленная

91. ОЦЕНКА РИСКА РАЗВИТИЯ ИНСУЛЬТА И СИСТЕМНЫХ ТРОМБОЭМБОЛИЙ У БОЛЬНЫХ С ФП БЕЗ ПОРАЖЕНИЯ КЛАПАНОВ СЕРДЦА ОПРЕДЕЛЯЕТСЯ ПО ШКАЛЕ
1) SCORE
2) CRUSADE
3) GRACE
4) CHA2DS2-VASc
5) HAS-BLED

92. К БОЛЬШИМ ФАКТОРАМ РИСКА ПРИ ОЦЕНКЕ ВЕРОЯТНОСТИ РАЗВИТИЯ ИНСУЛЬТА И СИСТЕМНЫХ ТРОМБОЭМБОЛИЙ У БОЛЬНЫХ С ФП БЕЗ ПОРАЖЕНИЯ КЛАПАНОВ СЕРДЦА ПО ШКАЛЕ CHА2DS2-VASc ОТНОСЯТСЯ
1) $\mathrm{A} \Gamma$
2) инсульт, ТИА или системная тромбоэмболия в анамнезе
3) возраст $\geq 75$ лет
4) женский пол
5) СД

93. К НОВЫМ ПЕРОРАЛЬНЫМ АНТИКОАГУЛЯНТАМ, ИСПОЛЬЗУЕМЫМ ДЛЯ ПРОФИЛАКТИКИ ИНСУЛЬТА ПРИ ФП ОТНОСЯТСЯ
1) дабигатран
2) ривароксабан
3) эпросартан
4) апиксабан
5) тикагрелор 
94. ПРИ НАЛИЧИИ КЛАПАННОЙ ФОРМЫ ФП ДЛЯ ПРОФИЛАКТИКИ ИНСУЛЬТА И СИСТЕМНЫХ ТРОМБОЭМБОЛИЙ НАЗНАЧАЕТСЯ
1) варфарин
2) ривароксабан
3) дабигатран
4) апиксабан

95. У ПАЦИЕНТОВ С ФП ДОЗА ВАРФАПИНА КОНТРОЛИРУЕТСЯ ПУТЕМ ОПРЕДЕЛЕНИЯ
1) $\mathrm{MHO}$
2) АЧТВ
3) ПТИ
4) ПВ

96. ЦЕЛЕВОЙ ПОКАЗАТЕЛЬ МНО ПРИ НАЗНАЧЕНИИ ВАРФАРИНА С ЦЕЛЬЮ ПРОФИЛАКТИКА ИНСУЛЬТА И ТРОМБОЭМБОЛИЧЕСКИХ ОСЛОЖНЕНИЙ У ПАЦИЕНТОВ С ФП
1) $1-2$
2) $2-3$
3) $3-4$
4) $1,2-2,2$

97. ТЕРАПИЯ ПЕРОРАЛЬНЫМИ АНТИКОАГУЛЯНТАМИ У ПАЦИЕНТОВ С ФП (ПРИ ОТСУТСТВИИ ПРОТИВОПОКАЗАНИЙ) ПОКАЗАНА

1) пациентам с количеством баллов по шкале CHA2DS2-VASc $\geq 2$

2) пациентам с количеством баллов по шкале CHA2DS2VASc $=0$ (включая женщин моложе 65 лет с изолированной ФП), что соответствует низкому риску и отсутствием других факторов риска

3) пациентам с количеством баллов по шкале CHA2DS2-VASc = 1

4) пациентам с количеством баллов по шкале CHA2DS2-VASc $=0,5$

5) пациентам с количеством баллов по шкале CHA2DS2-VASc $=0,9$

98. ДЛЯ ОЦЕНКИ РИСКА КРОВОТЕЧЕНИЙ У ПАЦИЕНТОВ ТРЕБУЮЩИХ НАЗНАЧЕНИЯ АНТИКОАГУЛЯНТНОЙ ТЕРАПИИ ИСПОЛЬЗУЕТСЯ ШКАЛА
1) SCORE
2) CRUSADE 

3) GRACE
4) CHA2DS2-VASc
5) HAS-BLED

99. ШКАЛА ОЦЕНКИ РИСКА КРОВОТЕЧЕНИЙ HAS-ВLЕD ВКЛЮЧАЕТ СЛЕДУЮЩИЕ ПОКАЗАТЕЛИ
1) $\mathrm{A} \Gamma$
2) нарушение функции печени и почек
3) инсульт
4) женский пол
5) кровотечение
6) возраст более 65 лет
7) лабильное МНО
8) прием алкоголя и некоторых лекарственных препаратов

100. ПРИ ЛЕЧЕНИИ ПАЦИЕНТОВ С ДЛИТЕЛЬНОСТЬЮ ПРИСТУПА ФП МЕНЕЕ 48 ЧАСОВ И ВЫСОКИМ РИСКОМ ИНСУЛЬТА РЕКОМЕНДУЕТСЯ

1) внутривенное введение нефракционированного или низкомолекулярного гепарина в дозах, применяемых для лечения венозных тромбозов, а затем длительная терапия антагонистами витамина К (варфарином) с целевым МНО 2,0-3,0

2) использование двойной антиагрегантной терапии

3) отказаться от антикоагулянтной терапии

4) назначение антикоагулянтной терапии в течение 2 недель до и 2 недель после кардиоверсии

101. НАЗНАЧЕНИЕ ТРОЙНОЙ АНТИТРОМБОТИЧЕСКОЙ ТЕРАПИИ (ВАРФАРИН, АЦЕТИЛСАЛИЦИЛОВАЯ КИСЛОТА, КЛОПИДОГРЕЛЬ) ПОСЛЕ ПЛАНОВОГО ЧКВ И ИМПЛАНТАЦИИ ГОЛОМЕТАЛЛИЧЕСКОГО СТЕНТА У ПАЦИЕНТОВ С ФП ПРОВОДИТСЯ В ТЕЧЕНИЕ

1) 1 месяца с последующим переходом на двойную антитромбоцитарную тапию в которой одним из препаратов является клопидогрель

2) 1 месяца с последующим переходом на двойную антитромбоцитарную тапию в которой одним из препаратов является варфарин

3) 6 месяцев с последующим переходом на двойную антитромбоцитарную тапию в которой одним из препаратов является варфарин 
4) 3 месяца с последующим переходом на монотерапию ацетилсалициловой кислотой

5) 1 месяца с последующим отказом от антитромбоцитарной терапии

102. НАЗНАЧЕНИЕ ТРОЙНОЙ АНТИТРОМБОТИЧЕСКОЙ ТЕРАПИИ (ВАРФАРИН, АЦЕТИЛСАЛИЦИЛОВАЯ КИСЛОТА, КЛОПИДОГРЕЛЬ) ПОСЛЕ ПЛАНОВОГО ЧКВ И ИМПЛАНТАЦИИ СТЕНТА, ВЫДЕЛЯЮЩЕГО ЛЕКАРСТВЕННЫЕ ПРЕПАРАТЫ, У ПАЦИЕНТОВ С ФП ПРОВОДИТСЯ В ТЕЧЕНИЕ

1) 3-6 месяцев с последующим переходом на двойную антитромбоцитарную тапию в которой одним из препаратов является варфарин

2) 1 месяца с последующим переходом на двойную антитромбоцитарную тапию в которой одним из препаратов является клопидогрель

3) 3-6 месяцев с последующим переходом на двойную антитромбоцитарную тапию включающую только антиагреганты

4) 12 месяцев с последующим переходом на двойную антитромбоцитарную тапию в которой одним из препаратов является варфарин

5) 3 месяца с последующим переходом на монотерапию ацетилсалициловой кислотой

103. ПОКАЗАНИЕМ ДЛЯ ЭКСТРЕННОЙ ЭЛЕКТРИЧЕСКОЙ КАРДИОВЕРСИИ ЯВЛЯЕТСЯ
1) нестабильность гемодинамики
2) пожелание пациента
3) непереносимость БАБ
4) наличие острой ишемии миокарда
5) неконтролируемая гипотензия
6) признаки $\mathrm{OCH}$

104. ИНТЕРВЕНЦИОННАЯ ЧРЕСКОЖНАЯ ОККЛЮЗИЯ УШКА ЛЕВОГО ПРЕДСЕРДИЯ У ПАЦИЕНТОВ С РИСКОМ ТРОМБОЭМБОЛИЙ ПРИ ФП ПРИМЕНЯЕТСЯ
1) только в случае отсутствия возможности использования дли- тельной терапии любыми пероральными антикоагулянтами
2) по желанию пациента
3) во всех клинических случаях 
4) при наличии значительной дилатации левого предсердия

5) при наличии митрального стеноза

105. НЕМЕДИКАМЕНТОЗНЫЕ МЕТОДЫ ЛЕЧЕНИЯ АГ ВКЛЮЧАЮТ

1) уменьшение веса

2) увеличение потребления воды

3) ограничение потребления поваренной соли до 5 г/сутки

4) увеличение потребления фруктов и овощей

5) повышение физической активности

6) ограничения алкоголя

7) отказ от курения

8) увеличение потребления белка

106. У ПАЦИЕНТОВ В ВОЗРАСТЕ СТАРШЕ 50 ЛЕТ ЛУЧШИМ ПРЕДИКТОРОМ КЛИНИЧЕСКИХ СОБЫТИЙ ЯВЛЯЕТСЯ
1) САД
2) ДАД
3) ПД
4) комбинация САД и ДАД
5) самочувствие пациента

107. К ПРЕДПОЧТИТЕЛЬНЫМ ЛЕКАРСТВЕННЫМ КОМБИНАЦИЯМ ДЛЯ ЛЕЧЕНИЯ АРТЕРИАЛЬНОЙ ГИПЕРТОНИИ ОТНОСЯТСЯ СОЧЕТАНИЯ
1) иАПФ + диуретик
2) иАПФ + бета-блокатор
3) иАПФ + антагонист кальция
4) БРА + диуретик
5) БРА + антагонист кальция
6) иАПФ + БРА

108. К ПРЕДПОЧТИТЕЛЬНЫМ ТРЕХКОМПОНЕНТНЫМ ЛЕКАРСТВЕННЫМ КОМБИНАЦИЯМ ДЛЯ ЛЕЧЕНИЯ АРТЕРИАЛЬНОЙ ГИПЕРТОНИИ ОТНОСЯТСЯ СОЧЕТАНИЯ

1) иАПФ + диуретик + бета-блокатор

2) иАПФ + бета-блокатор + антагонист кальция

3) иАПФ + антагонист кальция + диуретик

4) БРА + диуретик + бета-блокатор

5) БРА + антагонист кальция + диуретик

6) иАПФ + БРА + диуретик 
109. ПРИ АРТЕРИАЛЬНОЙ ГИПЕРТЕНЗИИ ЦЕЛЕВОЕ АД ДЛЯ ПАЦИЕНТОВ С НИЗКИМ И ВЫСОКИМ РИСКОМ СЕРДЕЧНО-СОСУДИСТЫХ ОСЛОЖНЕНИЙ НЕ ДОСТИГШИХ ЕЩЕ ПОЖИЛОГО ВОЗРАСТА СОСТАВЛЯЕТ
1) ниже чем $120 / 70$ мм рт.ст
2) ниже чем 130/80 мм рт.ст
3) ниже чем 140/85 мм рт.ст
4) ниже чем 140/90 мм рт.ст
5) ниже чем 150/90 мм рт.ст

110. ПРИ АРТЕРИАЛЬНОЙ ГИПЕРТЕНЗИИ ЦЕЛЕВОЕ АД ДЛЯ ПАЦИЕНТОВ С НИЗКИМ И ВЫСОКИМ РИСКОМ СЕРДЕЧНО-СОСУДИСТЫХ ОСЛОЖНЕНИЙ ДОСТИГШИХ ПОЖИЛОГО ВОЗРАСТА СОСТАВЛЯЕТ
1) ниже чем $120 / 70$ мм рт.ст
2) ниже чем 130/80 мм рт.ст
3) ниже чем 140/85 мм рт.ст
4) ниже чем 140/90 мм рт.ст
5) ниже чем 150/90 мм рт.ст

111. ПРИ АРТЕРИАЛЬНОЙ ГИПЕРТЕНЗИИ ЦЕЛЕВОЕ АД ДЛЯ ПАЦИЕНТОВ С САХАРНЫМ ДИАБЕТОМ СОСТАВЛЯЕТ
1) ниже чем $120 / 70$ мм рт.ст
2) ниже чем 130/80 мм рт.ст
3) ниже чем 140/85 мм рт.ст
4) ниже чем 140/90 мм рт.ст
5) ниже чем 150/90 мм рт.ст

112. РЕЗИСТЕНТНАЯ АРТЕРИАЛЬНАЯ ГИПЕРТОНИЯ ЭТО

1) изолированная систолическая гипертония

2) АГ, резистентная к лечению

3) превышение целевого уровня АД у пациента, вследствие невыполнения врачебных рекомендаций

4) превышение целевого уровня АД несмотря на лечение тремя гипотензивными препаратами, один из которых - диуретик.

5) рефрактерная $\mathrm{A} \Gamma$

113. НАИБОЛЕЕ РАСПРОСТРАНЕННОЙ ПРИЧИНОЙ РАЗВИТИЯ АОРТАЛЬНОГО СТЕНОЗА ЯВЛЯЕТСЯ

1) атеросклероз

2) ревматизм 

3) врожденные изменения
4) инфекционный эндокардит
5) сифилис

\section{4. ЭХОКАРДИОГРАФИЧЕКИМИ КРИТЕРИЯМИ ТЯЖЕЛОГО АОРТАЛЬНОГО СТЕНОЗА ЯВЛЯЮТСЯ}

1) площадь аортального отверстия $<0,5 \mathrm{~cm}^{2}$, градиент давления $>80$ мм рт.ст., максимальная скорость $>34,0$ м/с

2) площадь аортального отверстия $<1,0 \mathrm{~cm}^{2}$, градиент давления $>40$ мм рт.ст., максимальная скорость $>4,0$ м/с

3) площадь аортального отверстия $<2,0 \mathrm{~cm}^{2}$, градиент давления $>30$ мм рт.ст., максимальная скорость $>1,0$ м/с

4) площадь аортального отверстия $<3,0 \mathrm{~cm}^{2}$, градиент давления $>40$ мм рт.ст., максимальная скорость $>4,0$ м/с

5) площадь аортального отверстия $<1,0 \mathrm{~cm}^{2}$, градиент давления $>60$ мм рт.ст., максимальная скорость $>5,0$ м/с

\section{5. ЗАМЕНА АОРТАЛЬНОГО КЛАПАНА РЕКОМЕНДОВАНА}

1) всем пациентам с аортальным стенозом

2) пациентам с тяжелым аортальным стенозом и любыми симптомами, связанными с данным пороком

3) пациентам с тяжелым аортальным стенозом, которым планируется АКШ, либо другие операции на восходящей аорте или аортальном клапане

4) бессимптомным пациентам с тяжелым аортальным стенозом и систоличекой дисфункцией ЛЖ $(Ф В<50 \%)$, обусловленной данным пороком

5) бессимптомным пациентам с тяжелым аортальным стенозом и положительными результатами нагрузочных проб, четко связанными именно с данным пороком

\section{6. НАИБОЛЕЕ РАСПРОСТРАНЕННОЙ ПРИЧИНОЙ РАЗВИ- ТИЯ МИТРАЛЬНОГО СТЕНОЗА ЯВЛЯЕТСЯ}
1) атеросклероз
2) ревматизм
3) врожденные изменения
4) инфекционный эндокардит
5) сифилис 
117. ЧРЕСКОЖНАЯ МИТРАЛЬНАЯ КОМИССУРОТОМИЯ РЕКОМЕНДОВАНА

1) всем пациентам с митральным стенозом

2) только в детском возрате

3) пациентам с клинически значимым митральным стенозом (площадь отверстия $>1,5 \mathrm{~cm}^{2}$ ), любыми симптомами, связанными с данным пороком и анатомическими характеристиками, позволяющими выполнить данное вмешательство

4) пациентам с клинически значимым митральным стенозом (площадь отверстия $>1,5 \mathrm{~cm}^{2}$ ), любыми симптомами, связанными с данным пороком и противопоказаниями к открытому вмешательству

5) в качестве «терапии моста» у критических пациентов

6) бессимптомным пациентам с клинически значимым митральным стенозом (площадь отверстия $>1,5 \mathrm{~cm}^{2}$ ) и высоким риском тромбоэмболических осложнений

\section{8. ОРАЛЬНЫЕ АНТИКОАГУЛЯНТЫ РЕКОМЕНДОВАНЫ}

1) всем пациентам после операции протезирования клапана на протяжении только первых 3 месяцев

2) всем пациентам с механическими протезами клапанов пожизненно

3) всем пациентам с биопротезами клапанов, имеющими дополнительные показания к антикоагуляции пожизненно

4) пациентам с биопротезами клапанов на протяжении 3 месяцев после оперативного вмешательства

5) пожизненно только пациентам с протезированными клапанами и мерцательной аритмией

119. ЦЕЛЕВОЙ УРОВЕНЬ МНО ДЛЯ ПАЦИЕНТОВ С МЕХАНИЧЕСКИМИ ПРОТЕЗАМИ КЛАПАНОВ

1) всегда $2-3$

2) всегда 2,5-3,5

3) всегда $3-4$

4) зависит от тромбогенности механического клапана и составляет 2,5-3 - для клапанов с низкой тромбогенностью, $3-3,5-$ умеренной тромбогенностью, 3,5-4 - высокой тромбогенностью

5) зависит от индивидуальной переносимости и развития кровотечений или тромбоэмболий 
120. САМЫМ ЧАСТЫМ ВОЗБУДИТЕЛЕМ ИНФЕКЦИОННОГО ЭНДОКАРДИТА ЯВЛЯЕТСЯ
1) Staphylococcus aureus
2) Streptococus viridans
3) Pseudomonas aeruginosa
4) Candida albicans
5) Aspergillus

121. К БОЛЬШИМ КЛИНИЧЕСКИМ КРИТЕРИЯМ ИНФЕКЦИОННОГО ЭНДОКАРДИТА ОТНОСЯТСЯ

1) иммунологичекие феномены (узелки Ослера, пятна Рота, гломерулонефрит)

2) эхокардиографические признаки (свежие вегетации, абсцесс, вновь сформированная клапанная регургитация)

3) длительная лихорадка выше $38^{\circ} \mathrm{C}$

4) положительная гемокультура (возбудитель, согласующийся с инфекционным эндокардитом, выделенный при соблюдении следующих условий: два положительных результата в пробах взятых с интервалом не менее 12 часов, или три положительных результата из трех, или большинство положительных результатов из 4 проб и более с интервалом не менее часа)

5) любая положительная гемокультура

122. ВЫДЕЛЯЮТ СЛЕДУЮЩИЕ ВИДЫ КАРДИОМИОПАТИЙ
1) дилатационная
2) уремическая
3) рестриктивная
4) констриктивная
5) гипертрофическая

123. К БОЛЬШИМ КРИТЕРИЯМ РЕВМАТИЧЕСКОЙ ЛИХОРАДКИ ОТНОСЯТ
1) миокардит
2) мигрирующий полиартрит
3) ревматическую хорею
4) кольцевидную эритему
5) положительный ревматический фактор 
124. ДЛИТЕЛЬНАЯ АНТИБИОТИКОПРОФИЛАКТИКА У ПАЦИЕНТОВ С ПЕРЕНЕСЕННОЙ РЕВМАТИЧЕСКОЙ ЛИХОРАДКОЙ И СФОРМИРОВАННЫМ ПОРОКОМ СЕРДЦА

1) должна проводиться пожизненно

2) должна проводиться на протяжении 5 лет после последнего обострения или до достижения возраста 24 лет (в зависимости от того, что дольше)

3) 10 лет после последнего обострения или до достижения возраста 24 лет (в зависимости от того, что дольше)

4) 25 лет после последнего обострения или до достижения возраста 70 лет (в зависимости от того, что дольше)

5) не должна проводиться вообще

125. ЗОЛОТЫМ СТАНДАРТОМ ДИАГНОСТИКИ ТЭЛА ЯВЛЯЕТСЯ

1) ЭХО-КГ

2) вентиляционно-перфузионная сцинтиграфия

3) КТ-ангиография

4) спирография

5) рентгеногафия органов грудной клетки

6) определение D-димера

126. СКРИНИНГОВЫМ МЕТОДОМ ДИАГНОСТИКИ ТЭЛА НЕВЫСОКОГО РИСКА ЯВЛЯЕТСЯ
1) ЭХО-КГ
2) вентиляционно-перфузионная сцинтиграфия
3) КТ-ангиография
4) спирография
5) рентгеногафия органов грудной клетки
6) определение D-димера

127. ДЛЯ ОЦЕНКИ ТЯЖЕСТИ КЛИНИЧЕСКИХ ПРОЯВЛЕНИЙ ХСН ИСПОЛЬЗУЕТСЯ ИНДЕКС
1) ШOKC
2) SCORE
3) CRUSADE
4) GRACE
5) CHADS2

128. ДЛЯ ДИАГНОСТИКИ И ОЦЕНКИ ЭФФЕКТИВНОСТИ ЛЕЧЕНИЯ ХСН ИСПОЛЬЗУЕТСЯ ОПРЕДЕЛЕНИЕ УРОВНЯ

1) натрийуретического гормона

2) глюкозы 

3) калийуретического гормона
4) альбумина
5) железа ионизированного

129. ДЛЯ ВЫЯВИЯ ВОСПАЛИТЕЛЬНЫХ И ИНФИЛЬТРАТИВНЫХ ЗАБОЛЕВАНИЙ МИОКАРДА НАИБОЛЕЕ ИНФОРМАТИВНЫМ МЕТОДОМ ИССЛЕДОВАНИЯ ЯВЛЯЕТСЯ
1) магнитно-резонасная томография миокарда
2) чрезпищеводная ЭХО-КГ
3) стресс-ЭХО-КГ
4) $Э Х \mathrm{X}-\mathrm{K} \Gamma$
5) ЭКГ

130. У ПАЦИЕНТОВ С ХСН И СД ДЛЯ ПОДДЕРЖАНИЯ НОРМАЛЬНОГО УРОВНЯ ГЛИКЕМИИ ПРЕИМУЩЕСТВОМ ВЫБОРА (СРЕДИ ТАБЛЕТИРОВАННЫХ САХАРОСНИЖАЮЩИХ ПРЕПАРАТОВ) ОБЛАДАЕТ
1) толбутамид
2) метформин
3) глибенкламид
4) буформин
5) хлорпропамид

131. ПРИ ВЫБОРЕ КУРОРТА ПАЦИЕНТАМ С ХСН РЕКОМЕНДУЕТСЯ

1) пребывание в условиях высокогорья

2) пребывание в условиях высоких температур

3) пребывание в условиях высокой влажности

4) длительность перелета менее 2-2,5 часов

5) нахождение в привычной климатической зоне

132. ДЛЯ ЛЕЧЕНИЯ ХСН С ФВ МЕНЕЕ $40 \%$ К ГРУППЕ ПРЕПАРАТОВ ИСПОЛЬЗУЕМЫХ У ВСЕХ ПАЦИЕНТОВ ОТНОСЯТСЯ
1) иАПФ
2) сердечные гликозиды
3) БАБ
4) АРА (при непереносимости ИАПФ)
5) ивабрадин (при непереносимости БАБ и синусовом ритме)
6) AMKP 
133. ДЛЯ ПРОФИЛАКТИКИ ХСН У ПАЦИЕНТОВ С ХРОНИЧЕСКИМИ ЗАБОЛЕВАНИЯМИ ССС ВОЗМОЖНО ИСПОЛЬЗОВАНИЕ СЛЕДУЮЩИХ ИАПФ
1) периндоприл
2) эналаприл
3) рамиприл
4) трандолаприл
5) каптоприл

134. ДЛЯ ПРОФИЛАКТИКИ ХСН У ПАЦИЕНТОВ, ПЕРЕНЕСШИХ ОИМ, ПРИМЕНЯЮТСЯ
1) каптоприл
2) рамиприл
3) трандолаприл
4) фозиноприл
5) эналаприл
6) зофинаприл

135. У ПАЦИЕНТОВ С ХС И НАРУШЕННЫМИ ФУНКЦИЯМИ ПОЧЕК ПРЕПАРАТАМИ ВЫБОРА ЯВЛЯЮТСЯ
1) эналаприл
2) каптоприл
3) фозиноприл
4) спираприл
5) зофинаприл

136. ДЛЯ ЛЕЧЕНИЯ ХСН У ПАЦИЕНТОВ С НЕПЕРЕНОСИМОСТЬЮ ИАПФ ИСПОЛЬЗУЮТСЯ
1) кандесартан
2) эпросартан
3) валсартан
4) лозартан
5) ирбесартан

137. К ОДНИМ ИЗ ОСНОВНЫХ ПОЛОЖИТЕЛЬНЫХ СВОЙСТВ БАБ ИМЕЮЩИХ ЗНАЧЕНИЕ ПРИ ЛЕЧЕНИИ ХСН ОТНОСЯТСЯ СПОСОБНОСТЬ

1) снижать ЧСС

2) увеличивают потребность миокарда в кислороде

3) уменьшать степень ишемии миокарда в покое и особенно при физической активности 
4) оказывать антифибрилляторное действие, что снижает риск внезапной смерти

5) уменьшают дисфункцию и смерть кардиомиоцитов как путем некроза, так и апоптоз

6) увеличивают электрическую нестабильность миокарда

138. ДЛЯ ЛЕЧЕНИЯ ХСН У ПАЦИЕНТОВ ИСПОЛЬЗУЮТСЯ СЛЕДУЮЩИЕ БАБ
1) атенолол
2) бисопролол
3) метопролол сукцинат замедленного высвобождения
4) карведилол
5) небивалол
6) метопролол сукцинат ускоренного высвобождения

139. БАБ ПРИМЕНЯЮТСЯ ПРИ ЛЕЧЕНИИ ХСН

1) как препарат экстренной помощи при декомпенсации

2) как препарат экстренной помощи при гипергидратации

3) вместе с ИАПФ у больных с достигнутой стабилизацией состояния

4) при непереносимости ИАПФ

5) только при I ф.кл недостаточности кровообращения

140. ЛЕЧЕНИЕ МОЧЕГОННЫМИ У ПАЦИЕНТОВ С ХСН НАЧИНАЕТСЯ C

1) появления клинических или инструментальных признаков застоя

2) верификации I ф.кл. недостаточности кровообращения

3) появления в лабораторных анализах гипокалиемии

4) появления в лабораторных анализах гипонатриемии

5) появления в лабораторных анализах анемии

141. ОСНОВНЫМ ОТЛИЧИЕМ ТОРАСЕМИДА ОТ ДРУГИХ ПЕТЛЕВЫХ ДИУРЕТИКОВ ЯВЛЯЮТСЯ

1) дополнительные эффекты, связанные с одновременной мощной бета-адреноблокадой

2) дополнительные эффекты, связанные с одновременной блокадой РААС

3) назначение только в сочетании с верошпироном

4) не применяется у пациентов старше 60 лет

5) не применяется одновременно с иАПФ 
142. ПОКАЗАНИЯ ДЛЯ НАЗНАЧЕНИЯ АМКР У ПАЦИЕНТОВ С ХСН

1) применяются у всех больных XСН II-IV ФК и ФВ ЛЖ $<40 \%$

2) применяются у больных ХСН I ФК

3) применяются у всех больных, которые не переносят иАПФ

4) применяются у всех больных ХСН I-II ФК и ФВ ЛЖ $>40 \%$

5) применяются у всех больных ХСН

143. ПОКАЗАНИЯ ДЛЯ НАЗНАЧЕНИЯ СЕРДЕЧНЫХ ГЛИКОЗИДОВ У ПАЦИЕНТОВ С ХСН - ЭТО

1) больные XCH II-IV ФК и ФВ ЛЖ < $40 \%$ при ФП, с целью урежения и упорядочивания ритма

2) больные XCH I ФК

3) больные XCH II-IV ФК и ФВ ЛЖ $<40 \%$

4) больные XCH II-IV ФК и ФВ ЛЖ $<40 \%$ синусовым ритмом при недостаточной эффективности основных средств лечения декомпенсации

5) применяются у всех больных ХСН

144. ПОКАЗАНИЯМИ К СЕРДЕЧНОЙ РЕСИНХРОНИЗИРУЮЩЕЙ ТЕРАПИИ У ПАЦИЕНТОВ С СИНУСОВОМ РИТМОМ ЯВЛЯЮТСЯ

1) БЛНПГ (QRS > 120 мс), XCH І ф.кл. (по NYHA), ФВЛЖ > 35\% на фоне адекватной терапии

2) БЛНПГ (QRS > 120 мс), XCH II, III, IV (амбулаторного) ф.кл. (по NYHA), ФВЛЖ $\leq 35 \%$ на фоне адекватной терапии

3) Блокада не ЛНПГ (QRS > 150 мc), XCH II, III, IV (амбулаторного) ф.кл. (по NYHA), ФВЛЖ $\leq 35 \%$ на фоне адекватной терапии

4) QRS < 120 мс, XCH II, III, IV (амбулаторного) ф.кл. (по NYHA), ФВЛЖ $\leq 35 \%$ на фоне адекватной терапии

5) БЛНПГ (QRS > 120 мс), XCH II, III, IV (амбулаторного) ф.кл. (по NYHA), ФВЛЖ > 55\% на фоне адекватной терапии

145. ПОСТОЯННАЯ ЭКС ПОКАЗАНА ПРИ НАЛИЧИИ У ПАЦИЕНТА

1) AV-блокады I степени

2) AV-блокады III степени

3) AV-блокады II степени тип II

4) патологии синусового узла при наличии четкой ассоциации симтоматики и эпизодов брадикардии

5) БЛНПГ 
6) синкопальных состояний без однозначной корреляции с данными ЭКГ, но с наличием внутренней патологии синусового узла и бессимптомными паузами

146. КЛИНИЧЕСКИЕ СОСТОЯНИЯ, ТРЕБУЮЩИЕ ВРЕМЕННОЙ ОТМЕНЫ ПЛАНОВОЙ ВНЕСЕРДЕЧНОЙ ОПЕРАЦИИ, НЕМЕДЛЕННОГО ЛЕЧЕНИЯ И ОБСЛЕДОВАНИЯ

1) нестабильность коронарного кровотока

2) стенокардия напряжения II ф.кл.

3) декомпенсированная $\mathrm{XCH}$

4) выраженные нарушения ритма и проводимости

5) длительно существующая БЛНПГ

6) $\mathrm{A} \Gamma$

147. КОРОНАРОГРАФИЯ В ПЕРИОПЕРАЦИОННОМ ПЕРИОДЕ ВНЕСЕРДЕЧНЫХ ХИРУРГИЧЕСКИХ ВМЕШАТЕЛЬСТВ ПОКАЗАНА ПАЦИЕНТАМ С
1) AV-блокадой I степени
2) острым коронарным синдромом с подъемом сегмента ST
3) острым коронарным синдромом без подъма сегмента ST
4) патологией синусового узла
5) тяжелой стенокардией напряжения на фоне адекватной базо- вой терапии

148. ПЕРЕД ПЛАНОВЫМ ХИРУРГИЧЕСКИМ ВМЕШАТЕЛЬСТВОМ С ПРИМЕНЕНИЕМ ЭЛЕКТРОХИРУРГИЧЕСКОЙ ТЕХНИКИ У ПАЦИЕНТОВ С ЭКС РЕКОМЕНДОВАНО

1) перевод ЭКС в асинхронный режим стимуляции

2) отключить функцию частотной адаптации

3) повысить чувствительность, амплитуду (до заводских установок)

4) увеличить длительность импульса (до 1,0 мс)

5) отключить работу ЭКС

149. У ПАЦИЕНТОВ СО СТЕНОЗОМ ЛЕВОГО АТРИОВЕНТРИКУЛЯРНОГО ОТВЕРСТИЯ ПРОВЕДЕНИЕ ПЛАНОВОГО НЕКАРДИОЛОГИЧЕСКОГО ОПЕРАТИВНОГО ВМЕШАТЕЛЬСТВА ВОЗМОЖНО ПРИ УСЛОВИИ, ЧТО

1) площадь отверстия более $1,5 \mathrm{~cm}^{2}$

2) пациенты бессимптомны, площадь отверстия менее $1,5 \mathrm{~cm}^{2}$, но с систолическим давлением в легочной артерии менее 50 мм рт.ст. 
3) пациенты бессимптомны, площадь отверстия менее $1,5 \mathrm{~cm}^{2}$, но с систолическим давлением в легочной артерии более 50 мм рт.ст.

4) пациенты имеют клинику декомпенсации кровообращения, площадь отверстия более $1,5 \mathrm{~cm}^{2}$ и систолическим давлением в легочной артерии более 50 мм рт.ст.

5) пациент согласен на оперативное вмешательство

150. К ФАКТОРАМ, СПОСОБСТВУЮЩИМ ВЕРОЯТНОМУ ПОВТОРНОМУ СРЫВУ РИТМА И РЕЦИДИВИРОВАНИЮ ФП, ОТНОСЯТСЯ
1) выраженная гипертрофия ЛЖ
2) пожилой возраст (> 65 лет)
3) длительность ФП более 6 месяцев
4) женский пол
5) частые рецидивы ФП
6) переднее-задний размер левого предсердия более 4,2 cм
7) наличие тромбов в полостях сердца
8) ФВ ЛЖ менее $35 \%$ 


\section{ЗАДАЧИ}

Внимательно прочитайте условие каждой задачи. Выберите один или несколько правильных ответов на представленные по каждой задаче вопросы.

\section{Задача 1}

Пациентка $\Phi, 68$ лет 5 лет страдает артериальной гипертензией. У нее нет сахарного диабета, ИБС, но имеются проявления деформирующего остеортроза коленных суставов и наследственная отягощенность: отец пациентки умер от инфаркта в возрасте 52 лет. Курение отрицает. Антигипертензивные препараты ранее не принимала. Обратилась в связи с частым повышением АД, максимально до 175/105 мм рт.ст., сопровождающимся головной болью. При осмотре: ИМТ 32 кг/м², офисное АД 168/102 мм рт.ст., Левая граница сердца совпадает с верхушечным толчком и расположена на 1,5 см кнаружи от левой СКЛ. ЧСС 78 в 1 минуту, ритм правильный. При аускультации сердца - акцент 2 тона на аорте, дополнительных шумов нет. В легких везикулярное дыхание, хрипов нет. Отеков нет. Уровень общего холестерина - 6,7 ммоль/л, уровень креатинина 1,4 мг/дл $(\mathrm{CКФ}=39$ мл/мин/1,73 м²).

1. РИСК СЕРДЕЧНО-СОСУДИСТЫХ ОСЛОЖНЕНИЙ У ДАННОЙ ПАЦИЕНТКИ ОЦЕНИВАЕТСЯ КАК
1) низкий
2) средний
3) от низкого к среднему
4) высокий
5) от среднего к высокому
6) очень высокий
7) от высокого к очень высокому

2. ЦЕЛЕВОЕ АД ДЛЯ ДАННОЙ ПАЦИЕНТКИ СОСТАВЛЯЕТ
1) ниже чем $120 / 70$ мм рт.ст.
2) ниже чем 130/80 мм рт.ст.
3) ниже чем 140/85 мм рт.ст.
4) ниже чем 140/90 мм рт.ст.
5) ниже чем 150/90 мм рт.ст. 
3. ДАННОЙ ПАЦИЕНТКЕ В ПЕРВУЮ ОЧЕРЕДЬ ПОКАЗАНО ВЫПОЛНЕНИЕ СЛЕДУЮЩИХ РУТИННЫХ ИССЛЕДОВАНИЙ (ИЗ ПЕЧЕЧИСЛЕННЫХ)
1) ЭКГ
2) ДЭХОКГ
3) ЛПнП, ЛПвП
4) калий и натрий сыворотки крови
5) мочевая кислота сыворотки крови
6) гликированный гемоглобин

4. ЛЕЧЕБНАЯ ТАКТИКА У ДАННОЙ ПАЦИЕНТКИ ДОЛЖНА ВКЛЮЧАТЬ

1) только динамическое наблюдение за пациенткой

2) только изменение образа жизни

3) изменение образа жизни, назначение фармакотерапии

4) немедленное назначение фармакотерапии (на фоне изменений в образе жизни)

5) хирургическое вмешательство

5. В ДАННОМ СЛУЧАЕ РЕКОМЕНДОВАННОЙ НАЧАЛЬНОЙ ТАКТИКОЙ ФАРМАКОТЕРАПИИ ЯВЛЯЕТСЯ
1) монотерапия тиазидными диуретиками
2) монотерапия любым препаратом из рекомендованных клас- сов лекарственных средств
3) монотерапия любым из рекомендованных препаратов, кроме бета-блокаторов
4) комбинированная терапия из 2 препаратов
5) комбинированная терапия из 3 препаратов

6. РЕКОМЕНДОВАННЫМИ ВАРИАНТАМИ НАЧАЛЬНОЙ ФАРМАКОТЕРАПИИ АГ ДЛЯ ДАННОЙ ПАЦИЕНТКИ БУДУТ
1) ингибитор АПФ
2) ингибитор АПФ в комбинации с антагонистом кальция
3) ингибитор АПФ в комбинации с тиазидным диуретиком
4) бета-блокатор в комбинации с ингибитором АПФ
5) антагонист кальция
6) тиазидный диуретик

7. ДАННОЙ ПАЦИЕНТКЕ ТАКЖЕ РЕКОМЕНДОВАНЫ

1) аспирин

2) аспирин + клопидогрель 

3) статины
4) нитраты
5) петлевые диуретики
6) оральные контрацептивы

\section{Задача 2}

Мужчина Щ, 88 лет. В течение 5 лет страдает артериальной гипертензией. У него нет сахарного диабета. В анамнезе - перенесенный инфаркт миокарда 2 годами ранее, наследственная отягощенность: мать пациента умерла от инсульта в возрасте 52 лет. В настоящее время боли в грудной клетке не отмечает. Одышка беспокоит только при существенной физической нагрузке. Регулярно принимает аспирин 125 мг в сутки. Ранее принимал метопролол, но прекратил в связи с развитием брадикардии, и аторвастатин, прием которого прератил по финансовым соображениям. Обратился в связи с частыми подъемами АД, максимально до 180/115 мм рт.ст., сопровождающимися головной болью, слабостью, головокружением. При осмотре: ИМТ 27 кг $/ \mathrm{M}^{2}$, офисное АД 168/112 мм рт.ст. Левая граница сердца совпадает с верхушечным толчком и расположена на 1,5 см кнаружи от левой СКЛ. ЧСС 68 в 1 минуту, ритм правильный. При аускультации сердца - акцент 2 тона на аорте, систолический шум на верхушке сердца. В легких везикулярное дыхание, хрипов нет. Отеков нет. Уровень общего холестерина - 4,7 ммоль/л, СКФ $=51$ мл/мин/1,73 м². На ЭКГ - синусовый ритм с ЧСС 65 в 1 минуту. Отклонение электрической оси влево. Зубец S в V1 + R в V5,6 > 35 мм. Изменений по сегменту ST нет.

1. РИСК СЕРДЕЧНО-СОСУДИСТЫХ ОСЛОЖНЕНИЙ У ДАННОГО ПАЦИЕНТА ОЦЕНИВАЕТСЯ КАК
1) низкий
2) средний
3) от низкого к среднему
4) высокий
5) от среднего к высокому
6) очень высокий
7) от высокого к очень высокому

2. ЦЕЛЕВОЕ АД ДЛЯ ДАННОГО ПАЦИЕНТА СОСТАВЛЯЕТ
1) ниже чем $120 / 70$ мм рт.ст.
2) ниже чем 130/80 мм рт.ст.
3) ниже чем 140/85 мм рт.ст. 
4) ниже чем 140/90 мм рт.ст.

5) ниже чем 150/90 мм рт.ст.

3. ДАННОМУ ПАЦИЕНТУ ПОКАЗАНО ВЫПОЛНЕНИЕ СЛЕДУЮЩИХ ИССЛЕДОВАНИЙ, С УЧЕТОМ УЖЕ ИМЕЮЩИХСЯ РЕЗУЛЬТАТОВ (ИЗ ПЕЧЕЧИСЛЕННЫХ)
1) ЭКГ
2) ДЭХОКГ
3) ЛПНП, ЛПВП
4) калий и натрий сыворотки крови
5) холтеровское мониторирование
6) определение микроальбуминурии

4. ЛЕЧЕБНАЯ ТАКТИКА У ДАННОГО ПАЦИЕНТА ДОЛЖНА ВКЛЮЧАТЬ

1) только динамическое наблюдение за пациентом

2) только изменение образа жизни

3) изменение образа жизни, назначение фармакотерапии

4) немедленное назначение фармакотерапии (на фоне изменений в образе жизни)

5) хирургическое вмешательство

\section{5. В ДАННОМ СЛУЧАЕ РЕКОМЕНДОВАННОЙ НАЧАЛЬНОЙ} ТАКТИКОЙ ФАРМАКОТЕРАПИИ АРТЕРИАЛЬНОЙ ГИПЕРТЕНЗИИ ЯВЛЯЕТСЯ

1) монотерапия тиазидными диуретиками

2) монотерапия любым препаратом из рекомендованных классов лекарственных средств

3) монотерапия любым из рекомендованных препаратов, кроме бета-блокаторов

4) комбинированная терапия из 2 препаратов

5) комбинированная терапия из 3 препаратов

6. РЕКОМЕНДОВАННЫМИ ВАРИАНТАМИ НАЧАЛЬНОЙ ФАРМАКОТЕРАПИИ АГ ДЛЯ ДАННОГО ПАЦИЕНТА БУДУТ

1) ингибитор АПФ

2) ингибитор АПФ в комбинации с антагонистом кальция

3) ингибитор АПФ в комбинации с тиазидным диуретиком

4) бета-блокатор в комбинации с ингибитором АПФ

5) антагонист кальция

6) тиазидный диуретик 
7. ДАННОМУ ПАЦИЕНТУ ТАКЖЕ РЕКОМЕНДОВАНЫ
1) аспирин
2) аспирин + клопидогрель
3) статины
4) нитраты
5) петлевые диуретики
6) верошпирон

\section{Задача 3}

Пациентка А, 38 лет, наблюдается в женской консультации по поводу беременности, срок 14 недель. Первая беременность протекала без осложнений, закончилась рождением здорового ребенка. Страдает хроническим пиелонефритом в течение 15 лет. Страдает артериальной гипертонией в течение 11 лет. Максимальное АД 180/90 мм рт.ст. Лечилась регулярно. До беременности принимала престариум 10 мг в сутки. С начала беременности самостоятельно прекратила прием препарата, прочитав в инструкции к препарату о влиянии на плод. В течение первого триместра АД в пределах 130-135/80-85 мм рт.ст. В течение последних 2 недель АД 140-160/90 мм рт.ст., сопровождается сильной головной болью, сердцебиением. Других заболеваний нет. При осмотре: офисное АД 148/91 мм рт.ст. Левая граница сердца совпадает с верхушечным толчком и расположена на 0,5 см кнутри от левой СКЛ. ЧСС 78 в 1 минуту, ритм правильный. При аускультация сердца - без особенностей. В легких везикулярное дыхание, хрипов нет. Отеков нет. СКФ $=58$ мл/мин/1,73 м². На ЭКГ - синусовый ритм с ЧСС 76 в 1 минуту. ЭОС расположена обычно. Синдром ранней реполяризации. При ДЭХОКГ - пролапс митрального клапана. Признаков гипертрофии ЛЖ нет. В ОАМ - протеинурия.

\section{1. ЦЕЛЕВОЕ АД ДЛЯ ДАННОГО ПАЦИЕНТА СОСТАВЛЯЕТ}
1) ниже чем $120 / 70$ мм рт.ст.
2) ниже чем 130/80 мм рт.ст.
3) ниже чем 140/85 мм рт.ст.
4) ниже чем $140 / 90$ мм рт.ст.
5) ниже чем 150/90 мм рт.ст.

2. ЛЕЧЕБНАЯ ТАКТИКА У ДАННОЙ ПАЦИЕНТКИ ДОЛЖНА ВКЛЮЧАТЬ
1) только динамическое наблюдение за пациенткой
2) только изменение образа жизни 
3) изменение образа жизни, назначение фармакотерапии

4) немедленное назначение фармакотерапии (на фоне изменений в образе жизни)

5) прерывание беременности

3. КАКИЕ ГИПОТЕНЗИВНЫЕ ПРЕПАРАТЫ, ИЗ ПЕРЕЧИСЛЕННЫХ НИЖЕ, МОЖНО РЕКОМЕНДОВАТЬ ДАННОЙ ПАЦИЕНТКЕ
1) лабеталол
2) метилдопа
3) нифедипин
4) бисопролол
5) эналаприл
6) амлодипин

4. РИСК РАЗВИТИЯ ПРЕЭКЛАМПСИИ У ДАННОЙ ПАЦИЕНТКЕ ОЦЕНИВАЕТСЯ КАК
1) очень Низкий
2) низкий
3) умеренный
4) высокий
5) очень высокий

5. ДРУГИЕ ФАРМАКОЛОГИЧЕСКИЕ ПРЕПАРАТЫ, РЕКОМЕНДОВАННЫЕ ДАННОЙ ПАЦИЕНТКЕ ЭТО
1) аспирин
2) аспирин + клопидогрель
3) статины
4) нитраты
5) петлевые диуретики
6) оральные контрацептивы

\section{Задача 4}

Пациент К, 65 лет в течение 15 лет страдает артериальной гипертензией. В анамнезе - 2 перенесенных инфаркта миокарда, последний 2 года назад. У него нет сахарного диабета. В течение последних 10 лет отмечает появление одышки при небольшой нагрузке, эпизодически отеков нижних конечностей. Регулярно принимает эналаприл 5 мг 2 раза в сутки, кордарон 200 мг в сутки, бисопролол 2,5 мг в сутки, аспирин 125 мг в сутки, верошпирон 100 мг в сутки. Сегодня вечером отметил появление интенсивной загрудинной боли в покое, длительностью около 
40 минут, сопровождающейся интенсивной инспираторной одышкой. БСМП доставлен в отделение кардиологии. Боль и одышка волнообразно рецидивируют. При осмотре: Вынужденное положение с приподнятым изголовьем, АД 130/78 мм рт.ст. Левая граница сердца совпадает с верхушечным толчком и расположена на 2 см кнаружи от левой СКЛ. ЧСС 78 в 1 минуту, ритм синусовый. При аускультации сердца - акцент 2 тона на легочном стволе, систолический шум на верхушке сердца, на мечевидном отростке. В легких везикулярное дыхание, большое количество влажных незвучных мелкопузырчатых и средне-пузырчатых хрипов, занимающих $2 / 3$ легочных полей с 2 -х сторон. Отеков нет. На ЭКГ - синусовый ритм, патологический Q в II, III, AVF, депрессия ST I, AVL, V1-V6.

\section{1. У ДАННОГО ПАЦИЕНТА ИМЕЕТСЯ}
1) пневмония
2) острый коронарный синдром с подъемом сегмента ST
3) острый коронарный синдром без подъема сегмента ST
4) острая почечная недостаточность
5) $\mathrm{XCH}$

2. ОСЛОЖНЕНИЕМ УКАЗАННОГО СОСТОЯНИЯ У ДАННОГО ПАЦИЕНТА ЯВЛЯЕТСЯ
1) XCH НІІБ IV $Ф \mathrm{~K}$
2) $\mathrm{XCH}$ HIII III ФK
3) острая декомпенсированная сердечная недостаточность
4) отек легких
5) кардиогенный шок

3. ЛАБОРАТОРНЫЕ ПОКАЗАТЕЛИ, НЕОБХОДИМЫЕ ДЛЯ ОЦЕНКИ СОСТОЯНИЯ ДАННОГО ПАЦИЕНТА ЭТО
1) RW
2) креатинин сыворотки крови
3) альбумины
4) БНП/NT-проБНП
5) КФК-МВ и/или тропонины
6) сатурация кислорода

4. ДОПОЛНИТЕЛЬНЫЕ ИССЛЕДОВАНИЯ, ПОКАЗАННЫЕ ДАННОМУ ПАЦИЕНТУ (ПРИ НАЛИЧИИ ВОЗМОЖНОСТИ ИХ ВЫПОЛНЕНИЯ) ЭТО

1) трансторакальная ДЭХОКГ

2) чреспищеводная ДЭХОКГ 

3) рентгенография органов грудной клетки
4) холтеровское мониторирование
5) коронарография
6) УЗИ почек

5. АНТИТРОМБОТИЧЕСКИЕ ПРЕПАРАТЫ (ИЗ ПЕРЕЧИСЛЕННЫХ), ПОКАЗАННЫЕ ДАНОМУ ПАЦИЕНТУ ЭТО
1) аспирин
2) тикагрелор
3) тканевой активатор плазминогена
4) нефракционированный гепарин
5) дабигатран
6) ривароксабан

6. ДАННОМУ ПАЦИЕНТУ ТАКЖЕ ПОКАЗАНО (ИЗ ПЕРЕЧИСЛЕННОГО) НАЗНАЧЕНИЕ СЛЕДУЮЩИХ ПРЕПАРАТОВ
1) бета-блокатор
2) петлевой диуретик
3) ивабрадин
4) сердечные гликозиды
5) дофамин
6) нитроглицерин

7. ДАННОМУ ПАЦИЕНТУ ПОКАЗАНЫ СЛЕДУЮЩИЕ НЕМЕДИКАМЕНТОЗНЫЕ МЕТОДЫ ЛЕЧЕНИЯ
1) ЧКВ
2) имплантация кардиостимулятора
3) исскуственный левый желудочек
4) трансплантация сердца
5) интрааортальная балонная контрпульсация

\section{Задача 5}

Пациентка $\Phi, 68$ лет 10 лет страдает артериальной гипертензией. У нее нет сахарного диабета. Никакие препараты ранее не принимала. Сегодня вечером отметила появление впервые в жизни интенсивной загрудинной боли в покое, длительностью около 40 минут, сопровождающейся интенсивной инспираторной одышкой. БСМП доставлена в отделение кардиологии. При осмотре: Заторможена, вынужденное положение с приподнятым изголовьем, кожа бледная, холодная, акроцианоз. АД 88/49 мм рт.ст. Левая граница сердца совпадает с верхушечным 
толчком и расположена на 1,5 см кнаружи от левой СКЛ. ЧСС 78 в 1 минуту, ритм синусовый. При аускультации сердца - акцент 2 тона на легочном стволе, систолический шум на верхушке сердца, на мечевидном отростке. В легких везикулярное дыхание, большое количество влажных незвучных мелкопузырчатых и средне-пузырчатых хрипов, занимающих $2 / 3$ легочных полей с 2-х сторон. Отеков нет. На ЭКГ - синусовый ритм, патологический Q в I, II, элевация ST I, AVL, V1-V6. Какое осложнение имеется у данной пациентки?

\section{1. У ДАННОЙ ПАЦИЕНТКИ ИМЕЕТСЯ}
1) пневмония
2) острый коронарный синдром с подъемом сегмента ST
3) острый коронарный синдром без подъема сегмента ST
4) острая почечная недостаточность
5) инфаркт миокарда
6) $\mathrm{XCH}$

2. ОСЛОЖНЕНИЕМ(ЯМИ) УКАЗАННОГО СОСТОЯНИЯ У ДАННОЙ ПАЦИЕНТКИ ЯВЛЯЕТСЯ
1) XCH НІІБ IVФК
2) $\mathrm{XCH}$ HIII IIIФK
3) острая декомпенсированная сердечная недостаточность
4) отек легких
5) кардиогенный шок

3. ЛАБОРАТОРНЫЕ ПОКАЗАТЕЛИ, НЕОБХОДИМЫЕ ДЛЯ ОЦЕНКИ СОСТОЯНИЯ ДАННОЙ ПАЦИЕНТКИ ЭТО
1) $\mathrm{RW}$
2) креатинин сыворотки крови
3) альбумины
4) БНП/NT-проБНП
5) КФК-МВ и/или тропонины
6) сатурация кислорода

4. ДОПОЛНИТЕЛЬНЫЕ ИССЛЕДОВАНИЯ, ПОКАЗАННЫЕ ДАННОЙ ПАЦИЕНТКЕ (ПРИ НАЛИЧИИ ВОЗМОЖНОСТИ ИХ ВЫПОЛНЕНИЯ) ЭТО
1) трансторакальная ДЭХОКГ
2) чреспищеводная ДЭХОКГ
3) рентгенография органов грудной клетки 
4) холтеровское мониторирование

5) коронарография

6) УЗИ почек

5. НАИБОЛЕЕ ЗНАЧИМЫМ КОМПОНЕНТОМ ТЕРАПИИ ДАННОЙ ПАЦИЕНКИ ЯВЛЯЕТСЯ
1) назначение антиагрегантной и антикоагулянтной терапии
2) назначение бета-блокаторов
3) назначение блокаторов РААС
4) экстренное восстановление коронарного кровотока
5) назначение внутривенных диуретиков

6. ЕСЛИ ТАКТИКОЙ ДЛЯ ДАННОЙ ПАЦИЕНТКИ ЯВЛЯЕТСЯ ПЕРВИЧНЫЙ ТРОМБОЛИЗИС, ТО АНТИТРОМБОТИЧЕСКИМИ ПРЕПАРАТАМИ, ПОКАЗАННЫМИ ДАННОЙ ПАЦИЕНТКЕ (ИЗ ПЕРЕЧИСЛЕННОГО) ЯВЛЯЮСЯ
1) аспирин
2) тикагрелор
3) клопидогрель
4) бивалирудин
5) дабигатран
6) эноксапарин

7. ДАННОЙ ПАЦИЕНТКЕ ТАКЖЕ ПОКАЗАНО (ИЗ ПЕРЕЧИСЛЕННОГО) НАЗНАЧЕНИЕ СЛЕДУЮЩИХ ПРЕПАРАТОВ
1) бета-блокатор
2) петлевой диуретик
3) ивабрадин
4) сердечные гликозиды
5) дофамин
6) нитроглицерин

8. ДАННОЙ ПАЦИЕНТКЕ ТАКЖЕ ПОКАЗАНЫ СЛЕДУЮЩИЕ НЕМЕДИКАМЕНТОЗНЫЕ МЕТОДЫ ЛЕЧЕНИЯ
1) имплантация ресинхронизирующего устройства
2) имплантация кардиостимулятора
3) исскуственный левый желудочек
4) трансплантация сердца
5) интрааортальная балонная контрпульсация 


\section{Задача 6}

Мужчина Щ, 68 лет. В течение 5 лет страдает артериальной гипертензией. У него нет сахарного диабета. В анамнезе - перенесенный инфаркт миокарда 2 годами ранее, наследственная отягощенность: мать пациента умерла от инсульта в возрасте 52 лет. В течение последнего года отмечает появление одышки при умеренной нагрузке. В последние 1,5-2 месяца эпизодически отмечает появление отеков на нижних конечностях. Так же в течение 8 лет страдает аденомой предстательной железы. Ночные мочеиспускания 2-3 раза за ночь. Регулярно принимает амлодипин 5 мг в сутки, аспирин 125 мг в сутки, аторвастатин 20 мг в сутки. В течение нескольких дней отмечал уменьшение кол-ва мочи. С вечера накануне - мочеиспускания не было. Утром отметил появление интенсивной инспираторной одышки. БСМП доставлен в отделение кардиологии. При осмотре: Вынужденное положение с приподнятым изголовьем, АД 130/78 мм рт.ст. Левая граница сердца совпадает с верхушечным толчком и расположена на 2 см кнаружи от левой СКЛ. ЧСС 78 в 1 минуту, ритм синусовый. При аускультации сердца - акцент 2 тона на легочном стволе, систолический шум на верхушке сердца, на мечевидном отростке. В легких везикулярное дыхание, большое количество влажных незвучных мелкопузырчатых и средне-пузырчатых хрипов, занимающих $2 / 3$ легочных полей с 2-х сторон. Отеков нет. Мочевой пузырь определяется на 3 см выше лобка. На ЭКГ - синусовый ритм, патологический Q в II, III, AVF, депрессия ST I, AVL, V5-V6.

\section{1. У ДАННОГО ПАЦИЕНТА ИМЕЕТСЯ СЛЕДУЮЩЕЕ ОС-} ЛОЖНЕНИЕ
1) XCH НІІБ IVФК
2) XCH HIII IIIФK
3) острая декомпенсированная сердечная недостаточность
4) отек легких
5) кардиогенный шок

\section{2. ПРИЧИНОЙ РАЗВИТИЯ ТАКОГО ОСЛОЖНЕНИЯ В ДАННОМ} СЛУЧАЕ НАИБОЛЕЕ ВЕРОЯТНО ЯВЛЯЕТСЯ
1) пневмония
2) острый коронарный синдром с подъемом сегмента ST
3) острый коронарный синдром без подъема сегмента ST
4) острая почечная недостаточность
5) $\mathrm{XCH}$ 
3. ЛАБОРАТОРНЫЕ ПОКАЗАТЕЛИ, НЕОБХОДИМЫЕ ДЛЯ ОЦЕНКИ СОСТОЯНИЯ ДАННОГО ПАЦИЕНТА ЭТО
1) RW
2) креатинин сыворотки крови
3) БНП/NT-проБНП
4) КФК-МВ и/или тропонины
5) сатурация кислорода

4. ДОПОЛНИТЕЛЬНЫЕ ИССЛЕДОВАНИЯ, ПОКАЗАННЫЕ ДАННОМУ ПАЦИЕНТУ (ПРИ НАЛИЧИИ ВОЗМОЖНОСТИ ИХ ВЫПОЛНЕНИЯ) ЭТО
1) трансторакальная ДЭХОКГ
2) чреспищеводная ДЭХОКГ
3) рентгенография органов грудной клетки
4) холтеровское мониторирование
5) УЗИ предстательной железы
6) УЗИ почек

5. АНТИТРОМБОТИЧЕСКИЕ ПРЕПАРАТЫ (ИЗ ПЕРЕЧИСЛЕННЫХ), ПОКАЗАННЫЕ ДАНОМУ ПАЦИЕНТУ ЭТО
1) аспирин
2) тикагрелор
3) тканевой активатор плазминогена
4) нефракционированный гепарин
5) дабигатран
6) ривароксабан

6. ДАННОМУ ПАЦИЕНТУ ТАКЖЕ ПОКАЗАНО (ИЗ ПЕРЕЧИСЛЕННОГО) НАЗНАЧЕНИЕ СЛЕДУЮЩИХ ПРЕПАРАТОВ
1) бета-блокатор
2) петлевой диуретик
3) ивабрадин
4) сердечные гликозиды
5) дофамин
6) нитроглицерин

7. ДАННОМУ ПАЦИЕНТУ ПОКАЗАНЫ СЛЕДУЮЩИЕ НЕМЕДИКАМЕНТОЗНЫЕ МЕТОДЫ ЛЕЧЕНИЯ
1) ЧКВ
2) имплантация кардиостимулятора 
3) исскуственный левый желудочек

4) катетеризация мочевого пузыря

5) трансплантация сердца

6) интрааортальная балонная контрпульсация

\section{Задача 7}

Пациент A, 68 лет В течение 10 лет персистирующей мерцательной аритмией. У него нет сахарного диабета. В анамнезе - перенесенный ишемический инсульт 2 годами ранее. В течение последних 5 лет отмечает появление одышки при небольшой нагрузке. В последние 1,5-2 месяцев эпизодически отмечает появление отеков на нижних конечностях. Регулярно принимает эналаприл 5 мг 2 раза в сутки, кордарон 200 мг в сутки, аспирин 125 мг в сутки. Утром отметил внезапное появление сердцебиения и интенсивной инспираторной одышки. БСМП доставлен в отделение кардиологии. При осмотре: Вынужденное положение с приподнятым изголовьем, ИМТ 36 кг/м², офисное АД 120/80 мм рт.ст. Левая граница сердца совпадает с верхушечным толчком и расположена на 1,5 см кнаружи от левой СКЛ. ЧСС 118 в 1 минуту, мерцательная аритмия. При аускультации сердца - акцент 2 тона на аорте, систолический шум на верхушке сердца. В легких везикулярное дыхание, большое количество влажных незвучных мелкопузырчатых хрипов в нижних и средних отделах легких с 2-х сторон. Отеков нет. На ЭКГ - мерцательная аритмия. Отклонение электрической оси влево.

1. У ДАННОГО ПАЦИЕНТА ИМЕЕТСЯ СЛЕДУЮЩЕЕ ОСЛОЖНЕНИЕ 1) XCH НІІБ IVФК

2) XCH HIII IIIФK

3) острая декомпенсированная сердечная недостаточность

4) отек легких

5) кардиогенный шок

2. ПРИЧИНОЙ РАЗВИТИЯ ТАКОГО ОСЛОЖНЕНИЯ В ДАННОМ СЛУЧАЕ НАИБОЛЕЕ ВЕРОЯТНО ЯВЛЯЕТСЯ
1) пневмония
2) острый коронарный синдром с подъемом сегмента ST
3) острый коронарный синдром без подъема сегмента ST
4) острая почечная недостаточность
5) персистирующая мерцательная аритмия 
3. ЛАБОРАТОРНЫЕ ПОКАЗАТЕЛИ, НЕОБХОДИМЫЕ ДЛЯ ОЦЕНКИ СОСТОЯНИЯ ДАННОГО ПАЦИЕНТА ЭТО
1) RW
2) креатинин сыворотки крови
3) БНП/NT-проБНП
4) КФК-МВ и/или тропонины
5) сатурация кислорода

4. ДОПОЛНИТЕЛЬНЫЕ ИССЛЕДОВАНИЯ, ПОКАЗАННЫЕ ДАННОМУ ПАЦИЕНТУ (ПРИ НАЛИЧИИ ВОЗМОЖНОСТИ ИХ ВЫПОЛНЕНИЯ) ЭТО
1) трансторакальная ДЭХОКГ
2) чреспищеводная ДЭХОКГ
3) рентгенография органов грудной клетки
4) холтеровское мониторирование
5) УЗИ предстательной железы
6) УЗИ почек

5. НАИБОЛЕЕ ЗНАЧИМЫМ КОМПОНЕНТОМ ТЕРАПИИ ДАННОГО ПАЦИЕНТА ЯВЛЯЕТСЯ
1) назначение антиагрегантной и антикоагулянтной терапии
2) назначение бета-блокаторов
3) электрическая кардиоверсия
4) медикаментозная кардиоверсия
5) экстренное восстановление коронарного кровотока
6) назначение внутривенных диуретиков

6. АНТИТРОМБОТИЧЕСКИЕ ПРЕПАРАТЫ (ИЗ ПЕРЕЧИСЛЕННЫХ), ПОКАЗАННЫЕ ДАНОМУ ПАЦИЕНТУ В НАСТОЯЩЕЕ ВРЕМЯ ЭТО
1) аспирин
2) тикагрелор
3) тканевой активатор плазминогена
4) нефракционированный гепарин
5) дабигатран
6) ривароксабан

7. ДАННОМУ ПАЦИЕНТУ ТАКЖЕ ПОКАЗАНО (ИЗ ПЕРЕЧИСЛЕННОГО) НАЗНАЧЕНИЕ СЛЕДУЮЩИХ ПРЕПАРАТОВ

1) бета-блокатор

2) петлевой диуретик 

3) ивабрадин
4) сердечные гликозиды
5) дофамин
6) нитроглицерин

\section{Задача 8}

Пациент X, 71 год в течение 45 лет артериальной гипертензией, и в течение 25 лет - ИБС. В анамнезе -3 перенесенных инфаркта миокарда, последний 2 года назад. У него нет сахарного диабета. В течение последних 10 лет года отмечает появление одышки при небольшой нагрузке, эпизодически - отеков нижних конечностей. Отмечает частые (3-4 раза в год) декомпенсации сердечной недостаточности в виде появления одышки в покое, и в горизонтальном положении, снижение толерантности к физической нагрузке, частых приступах загрудинной боли при нагрузке и в покое, появления выраженных отеков. В настоящее время - одышка при небольшой нагрузке. Регулярно принимал эналаприл 5 мг 2 раза в сутки, карведилол 12,5 мг 2 раза в сутки, аспирин 125 мг в сутки, фуросемид 20 мг в сутки, верошпирон - 50 мг в сутки, однако в последнюю неделю отказался от приема мочегонных препаратов (решил «отдохнуть» от них). В течение последней недели отметил вновь появление одышки в покое, и в горизонтальном положении, снижение толерантности к физической нагрузке, появление выраженных отеков, асцита. При осмотре: ИМТ 32 кг/м², офисное АД 110/68 мм рт.ст. Левая граница сердца совпадает с верхушечным толчком и расположена на 2 см кнаружи от левой СКЛ. ЧСС 78 в 1 минуту, ритм синусовый. При аускультации сердца - акцент 2 тона на аорте, систолический шум на верхушке сердца, на мечевидном отростке. В легких везикулярное дыхание, большое количество влажных незвучных мелкопузырчатых хрипов в нижних отделах легких с 2-х сторон. Отеков нет. На ЭКГ - синусовый ритм, ПБЛНПГ, QRS = 125 мс. При ДЭХОКГ - клапанной патологии не выявлено, митральная и трикуспидальная регургитация тяжелой степени, зоны гипо-акинезии в передней стенке и перегородке, значительная дилатация полостей ЛЖ, ЛП, умеренная дилатация - ПЖ, ПП, ФВ $27 \%$, декомпенсация кровообращения по обоим кругам. Какое осложнение имеется у данного пациента?

\section{1. У ДАННОГО ПАЦИЕНТА ИМЕЕТСЯ СЛЕДУЮЩЕЕ ОСЛОЖНЕНИЕ 1) $\mathrm{XCH} \mathrm{НІІБ} \mathrm{IVФK}$ \\ 2) XCH HIII IIIФK \\ 3) острая декомпенсированная сердечная недостаточность}


4) отек легких

5) кардиогенный шок

2. ПРИЧИНОЙ РАЗВИТИЯ ТАКОГО ОСЛОЖНЕНИЯ В ДАННОМ СЛУЧАЕ НАИБОЛЕЕ ВЕРОЯТНО ЯВЛЯЕТСЯ
1) недостаточная приверженность к лечению
2) острый коронарный синдром с подъемом сегмента ST
3) острый коронарный синдром без подъема сегмента ST
4) острая почечная недостаточность
5) персистирующая мерцательная аритмия

3. ЛАБОРАТОРНЫЕ ПОКАЗАТЕЛИ, НЕОБХОДИМЫЕ ДЛЯ ОЦЕНКИ СОСТОЯНИЯ ДАННОГО ПАЦИЕНТА ЭТО
1) RW
2) креатинин сыворотки крови
3) БНП/NT-проБНП
4) КФК-МВ и/или тропонины
5) сатурация кислорода

4. ДОПОЛНИТЕЛЬНЫЕ ИССЛЕДОВАНИЯ, ПОКАЗАННЫЕ ДАННОМУ ПАЦИЕНТУ (ПРИ НАЛИЧИИ ВОЗМОЖНОСТИ ИХ ВЫПОЛНЕНИЯ) ЭТО
1) трансторакальная ДЭХОКГ
2) чреспищеводная ДЭХОКГ
3) рентгенография органов грудной клетки
4) холтеровское мониторирование
5) УЗИ почек

5. АНТИТРОМБОТИЧЕСКИЕ ПРЕПАРАТЫ (ИЗ ПЕРЕЧИСЛЕННЫХ), ПОКАЗАННЫЕ ДАНОМУ ПАЦИЕНТУ В НАСТОЯЩЕЕ ВРЕМЯ ЭТО
1) аспирин
2) клопидогрель
3) тканевой активатор плазминогена
4) нефракционированный гепарин
5) дабигатран
6) ривароксабан

6. ДАННОМУ ПАЦИЕНТУ ТАКЖЕ ПОКАЗАНО (ИЗ ПЕРЕЧИСЛЕННОГО) НАЗНАЧЕНИЕ СЛЕДУЮЩИХ ПРЕПАРАТОВ

1) бета-блокатор

2) петлевой диуретик 

3) ивабрадин
4) дофамин
5) иАПФ

7. ДАННОМУ ПАЦИЕНТУ МОГУТ БЫТЬ ПОКАЗАНЫ СЛЕДУЮЩИЕ НЕМЕДИКАМЕНТОЗНЫЕ МЕТОДЫ ЛЕЧЕНИЯ
1) ЧКВ
2) имплантация кардиостимулятора
3) исскуственный левый желудочек
4) имплантация ресинхронизирующего устройства
5) трансплантация сердца
6) интрааортальная балонная контрпульсация

\section{Задача 9}

Пациентка А, 55 лет 10 лет страдает артериальной гипертензией. Антигипертензивные препараты ранее постоянно не принимала. 20 лет страдает сахарным диабетом. Постоянно принимает метформин 500 мг 2 раза в сутки. Данных за ИБС нет. После сильного стресса на работе внезапно отметила появление сердцебиения, ощущение дрожи в теле, сильную головную боль. Обратилась в медицинскую часть завода. При осмотре: ИМТ 32 кг/м², при измерении АД 200/102 мм рт.ст., Левая граница сердца совпадает с верхушечным толчком и расположена на 1,5 cм кнаружи от левой СКЛ. ЧСС 98 в 1 минуту, ритм правильный. При аускультации сердца - акцент 2 тона на аорте, дополнительных шумов нет. В легких везикулярное дыхание, хрипов нет. Отеков нет. На ЭКГ - синусовый ритм с ЧСС 90 в 1 минуту, ЭОС отклонена влево, депрессия сегмента ST I, AVL, V5-V6.

1. У ДАННОЙ ПАЦИЕНТКИ ИМЕЕТСЯ СЛЕДУЮЩЕЕ ОСЛОЖНЕНИЕ

1) высокое АД

2) неосложненный гипертонический криз

3) осложненный гипертонический криз

4) пароксизм мерцательной аритмии

5) нейро-циркуляторная дистония

2. ТИП ГК У ДАННОЙ ПАЦИЕНТКИ МОЖНО ОХАРКТЕРИЗОBATЬ KAK
1) ГК I типа
2) ГК ІІ типа
3) адреналовый ГК 

4) норадреналовый ГК
5) нейро-вегетативная форма ГК
6) отечная форма ГК
7) судорожная форма ГК

\section{3. ТАКТИКОЙ ЛЕЧЕНИЯ ДАННОЙ ПАЦИЕНТКИ ЯВЛЯЕТСЯ}
1) только назначение плановой терапии АГ
2) постепенное снижение АД пероральными препаратами, на- блюдение в течение суток
3) быстрое снижение АД внутривенными препаратами на 10-15\% за 30-60 минут
4) максимально быстрое снижение АД до уровня САД $110-120$ мм рт.ст.
5) АД не должно снижаться

4. ГИПОТЕНЗИВНЫМИ ПРЕПАРАТАМИ, ПОКАЗАННЫМИ ДАННОЙ ПАЦИЕНТКЕ В НАСТОЯЩИЙ МОМЕНТ МОГУТ ЯВЛЯТЬСЯ
1) нифедипин перорально
2) каптоприл перорально
3) лабеталол перорально
4) эсмолол внутривенно
5) фуросемид внутривенно
6) эналаприлат внутривенно

5. ДАННОЙ ПАЦИЕНТКЕ МОЖЕТ БЫТЬ РЕКОМЕНДОВАН СЛЕДУЮЩИЙ ВАРИАНТ ПОСТОЯННОЙ ГИПОТЕНЗИВНОЙ ТЕРАПИИ
1) ингибитор АПФ
2) ингибитор АПФ в комбинации с антагонистом кальция
3) ингибитор АПФ в комбинации с тиазидным диуретиком
4) бета-блокатор в комбинации с ингибитором АПФ
5) антагонист кальция
6) тиазидный диуретик

\section{Задача 10}

Пациентка Н, 36 лет. В течение 5 лет страдает артериальной гипертензией. У нее нет сахарного диабета. В анамнезе - хронический пиелонефрит (по данным выписки при УЗИ почек - нефроптоз, СКФ $=58$ мл/мин/1,73 м²), наследственная отягощенность: мать пациентки умерла от инсульта в возрасте 52 лет. Регулярно принимает индапамид-ретард 1,5 мг в сутки. На этом фоне АД в нормотензивном 
диапазоне. В течение последних двух дней отмечала появление эпизодов головной боли, нарастала слабость, снизилась работоспособность. АД было в пределах 130-140/90 мм рт.ст., несмотря на прием индапамида. Сегодня утром отметила очень интенсивную головную боль, не снимающуюся анальгетиками, отечность лица, рук. АД 160/90 мм рт.ст. Дополнительно к индапамиду приняла метопролол 50 мг. АД снизилось, но через 1,5-2 часа возобновилась головная боль и АД при измерении в поликлинике - 180/100 мм рт.ст. При осмотре: ИМТ 27 кг/м². Левая граница сердца совпадает с верхушечным толчком и расположена на 1,5 см кнутри от левой СКЛ. ЧСС 68 в 1 минуту, ритм правильный. При аускультации сердца - акцент 2 тона на аорте, систолический шум на верхушке сердца. В легких везикулярное дыхание, хрипов нет. Отеков нет. На ЭКГ - синусовый ритм с ЧСС 76 в 1 минуту. ЭОС расположена обычно. Синдром ранней реполяризации.

1. У ДАННОЙ ПАЦИЕНТКИ ИМЕЕТСЯ СЛЕДУЮЩЕЕ ОСЛОЖНЕНИЕ

1) высокое АД

2) неосложненный гипертонический криз

3) осложненный гипертонический криз

4) пароксизм мерцательной аритмии

5) нейро-циркуляторная дистония

2. ТИП ГК У ДАННОЙ ПАЦИЕНТКИ МОЖНО ОХАРКТЕРИЗОВАТЬ КАК

1) ГК І типа

2) ГК ІІ типа

3) адреналовый ГК

4) норадреналовый ГК

5) нейро-вегетативная форма ГК

6) отечная форма ГК

7) судорожная форма ГК

3. ТАКТИКОЙ ЛЕЧЕНИЯ ДАННОЙ ПАЦИЕНТКИ ЯВЛЯЕТСЯ

1) только назначение плановой терапии АГ

2) постепенное снижение АД пероральными препаратами, наблюдение в течение суток

3) быстрое снижение АД внутривенными препаратами на 10-15\% за 30-60 минут

4) максимально быстрое снижение АД до уровня САД 110120 мм рт.ст.

5) АД не должно снижаться 
4. ГИПОТЕНЗИВНЫМИ ПРЕПАРАТАМИ, ПОКАЗАННЫМИ ДАННОЙ ПАЦИЕНТКЕ В НАСТОЯЩИЙ МОМЕНТ МОГУТ ЯВЛЯТЬСЯ
1) нифедипин перорально
2) каптоприл перорально
3) лабеталол перорально
4) фуросемид перорально
5) фуросемид внутривенно
6) эналаприлат внутривенно

5. ДАННОЙ ПАЦИЕНТКЕ МОЖЕТ БЫТЬ РЕКОМЕНДОВАН СЛЕДУЮЩИЙ ВАРИАНТ ПОСТОЯННОЙ ГИПОТЕНЗИВНОЙ ТЕРАПИИ (ИЗ ПЕРЕЧИСЛЕННОГО)
1) добавить к принимаемому индапамиду иАПФ (в низких дозах)
2) добавить к принимаемому индапамиду антагонист кальция (в низких дозах)
3) добавить к принимаемому индапамиду бета-блокатор (в низ- ких дозах)
4) продолжить монотерапию индапамидом
5) заменить диуретик на бета-блокатор
6) заменить диуретик на иАПФ

\section{Задача 11}

Пациент А, 48 лет. Ранее ничем не болел. Во время измерения АД (решил измерить за компанию с женой) отметил повышение до 158/90 мм рт.ст. Никаких симптомов не было. Далее в течение последних 2 недель неоднократно фиксировал АД в интервале 140-170/95 мм рт.ст., которое иногда сопровождалось легкой головной болью. Обратился в поликлинику. Никаких субъективных ощущений на момент обращения не отмечал. При осмотре: офисное АД 178/101 мм рт.ст. Левая граница сердца совпадает с верхушечным толчком и расположена на 1,5 см каружи от левой СКЛ. ЧСС 78 в 1 минуту, ритм правильный. При аускультация сердца - без особенностей. В легких везикулярное дыхание, хрипов нет. Отеков нет. На ЭКГ - синусовый ритм с ЧСС 76 в 1 минуту. ЭОС расположена обычно. Синдром ранней реполяризации.

\section{1. У ДАННОГО ПАЦИЕНТА ИМЕЕТСЯ СЛЕДУЮЩЕЕ СОСТОЯНИЕ 1) высокое АД \\ 2) неосложненный гипертонический криз \\ 3) осложненный гипертонический криз \\ 4) пароксизм мерцательной аритмии \\ 5) нейро-циркуляторная дистония}


2. ТИП ГК У ДАННОГО ПАЦИЕНТА МОЖНО ОХАРКТЕРИЗОBATЬ KAK
1) ГК І типа
2) ГК ІІ типа
3) нейро-вегетативная форма ГК
4) отечная форма ГК
5) судорожная форма ГК
6) у пациента нет гипертонического криза

\section{3. ТАКТИКОЙ ЛЕЧЕНИЯ ДАННОГО ПАЦИЕНТА ЯВЛЯЕТСЯ}

1) только назначение плановой терапии АГ

2) постепенное снижение АД пероральными препаратами, наблюдение в течение суток

3) быстрое снижение АД внутривенными препаратами на 10-15\% за 30-60 минут

4) максимально быстрое снижение АД до уровня САД 110120 мм рт.ст.

5) АД не должно снижаться

4. ГИПОТЕНЗИВНЫМИ ПРЕПАРАТАМИ, ПОКАЗАННЫМИ ДАННОМУ ПАЦИЕНТУ В НАСТОЯЩИЙ МОМЕНТ МОГУТ ЯВЛЯТЬСЯ
1) нифедипин перорально
2) каптоприл перорально
3) лабеталол перорально
4) фуросемид внутривенно
5) эналаприлат внутривенно
6) никакие препараты пациенту экстренно не показаны

5. ДАННОМУ ПАЦИЕНТУ МОЖЕТ БЫТЬ РЕКОМЕНДОВАН СЛЕДУЮЩИЙ ВАРИАНТ ПОСТОЯННОЙ ГИПОТЕНЗИВНОЙ ТЕРАПИИ (ИЗ ПЕРЕЧИСЛЕННОГО)
1) ингибитор АПФ
2) ингибитор АПФ в комбинации с антагонистом кальция
3) ингибитор АПФ в комбинации с тиазидным диуретиком
4) бета-блокатор в комбинации с ингибитором АПФ
5) антагонист кальция
6) тиазидный диуретик

\section{Задача 12}

Пациент Ж, 69 лет. Ранее ничем не болел. Неоднократно фиксировал АД 140-160/90 мм рт.ст., которое иногда сопровождалось легкой 
головной болью. Не обследовался не лечился. Внезапно рано утром отметил онемение лица, нарушение речи. Жена пациента вызвала скорую помощь. К моменту ее приезда пациент потерял сознание. Доставлен в стационар. При осмотре: АД 220/110 мм рт.ст. Левая граница сердца совпадает с верхушечным толчком и расположена на 1,5 см кнаружи от левой СКЛ. ЧСС 100 в 1 минуту, мерцательная аритмия. При аускультация сердца - систолический шум на верхушке, акцент 2 тона на аорте. В легких везикулярное дыхание, влажные незвучные мелкопузырчатые хрипы в нижних отделах легких. Отеков нет. На ЭКГ - мерцательная аритмия, с средней ЧСC 100-110 в 1 минуту. Изменений по ST-T нет.

1. У ДАННОГО ПАЦИЕНТА ИМЕЕТСЯ СЛЕДУЮЩЕЕ СОСТОЯНИЕ
1) высокое АД
2) неосложненный гипертонический криз
3) осложненный гипертонический криз
4) пароксизм мерцательной аритмии
5) нейро-циркуляторная дистония

2. ДИФФЕРЕНЦИАЛЬНЫЙ ДИАГНОЗ В ДАННОМ СЛУЧАЕ БУДЕТ ВЕСТИСЬ МЕЖДУ
1) нестабильной стенокардией
2) инфарктом миокарда
3) геморрагическим инсультом
4) ишемическим инсультом
5) ТИА
6) внезапной сердечной смертью

\section{3. ТАКТИКОЙ ЛЕЧЕНИЯ ДАННОГО ПАЦИЕНТА ЯВЛЯЕТСЯ}

1) только назначение плановой терапии АГ

2) постепенное снижение АД пероральными препаратами, наблюдение в течение суток

3) быстрое снижение АД внутривенными препаратами на 10-15\% за 30-60 минут

4) максимально быстрое снижение АД до уровня САД 110120 мм рт.ст.

5) мониторирование состояния пациента, АД не должно снижаться

4. ГИПОТЕНЗИВНЫМИ ПРЕПАРАТАМИ, ПОКАЗАННЫМИ ДАННОМУ ПАЦИЕНТУ В НАСТОЯЩИЙ МОМЕНТ МОГУТ ЯВЛЯТЬСЯ
1) нифедипин перорально
2) каптоприл перорально 
3) лабеталол перорально

4) фуросемид внутривенно

5) эналаприлат внутривенно

6) никакие препараты пациенту экстренно не показаны

\author{
5. ТАКТИКА В ОТНОШЕНИИ ГИПОТЕНЗИВНОЙ ТЕРАПИИ \\ У ДАННОГО ПАЦИЕНТА БУДЕТ ОПРЕДЕЛЯТЬСЯ \\ 1) только уровнем АД \\ 2) только степенью риска сердечно-сосудистых осложнений \\ 3) динамикой неврологической симптоматики и ее ассоциацией \\ с уровнем АД \\ 4) проведением или нет тромболитической терапии \\ 5) характером инсульта (ишемический/геморрагический)
}

\title{
Задача 13
}

Пациент K, 65 лет в течение 15 лет страдает артериальной гипертензией и в течение 10 лет - мерцательной аритмией. Первоначально приступы аритмии чередовались с периодами синусового ритма, в последние 5 лет - ритм мерцательная аритмия. У него нет сахарного диабета, проявлений ИБС. В течение последних 2 лет отмечает появление одышки при небольшой нагрузке, эпизодически - отеков нижних конечностей, в основном связанные с эпизодами сердцебиения. В настоящее время одышка беспокоит только при существенных физических нагрузках. Регулярно принимает эналаприл 5 мг 2 раза в сутки, бисопролол 2,5 мг в сутки, аспирин 125 мг в сутки, верошпирон 100 мг в сутки. Обратился в поликлинику для проведения планового обследования. При осмотре: АД 140/78 мм рт. ст. Левая граница сердца совпадает с верхушечным толчком и расположена на 2 см кнаружи от левой СКЛ. ЧСС 89 в 1 минуту, мерцательная аритмия. При аускультации сердца - акцент 2 тона на легочном стволе, систолический шум на верхушке сердца, на мечевидном отростке. В легких везикулярное дыхание, хрипов нет. Отеков нет. На ЭКГ - мерцательная аритмия с средней ЧСС 90 в 1 минуту, депрессия ST I, AVL, V1-V6.

\section{1. У ДАННОГО ПАЦИЕНТА ИМЕЕТСЯ СЛЕДУЮЩАЯ ФОРМА МЕРЦАТЕЛЬНОЙ АРИТМИИ}
1) пароксизмальная
2) персистирующая
3) длительно персистирующая
4) постоянная
5) впервые выявленная 
2. ИЗ ПЕРЕЧИСЛЕННОГО, ДАННОМУ ПАЦИЕНТУ ПОКАЗАНО ВЫПОЛНЕНИЕ
1) трансторакальной ДЭХОКГ
2) чреспищеводной ДЭХОКГ
3) рентгенографии органов грудной клетки
4) холтеровского мониторирования
5) пробы с физической нагрузкой
6) коронарография

\section{3. ДАННОМУ ПАЦИЕНТУ ПОКАЗАНО}
1) немедленное выполнение медикаментозной кардиоверсии
2) немедленное выполнение электрической кардиоверсии
3) 4-недельная антикоагулянтная терапия с последующей кар- диоверсией
4) контроль ЧСС
5) контроль ритма

4. В КАЧЕСТВЕ АНТИТРОМБОТИЧЕСКОЙ ТЕРАПИИ ДАННОМУ ПАЦИЕНТУ МОГУТ БЫТЬ НАЗНАЧЕНЫ СЛЕДУЮЩИЕ ВАРИАНТЫ ТЕРАПИИ
1) аспирин
2) клопидогрель
3) тикагрелор
4) варфарин
5) дабигатран
6) ривароксабан
7) апиксабан

5. В КАЧЕСТВЕ АНТИАРИТМИЧЕСКОГО ПРЕПАРАТА, У ДАННОГО ПАЦИЕНТА В НАСТОЯЩЕЕ ВРЕМЯ ВОЗМОЖНО ПРИМЕНЕНИЕ
1) дигоксин
2) бета-блокаторы
3) амиодарон
4) соталол
5) пропафенон
6) аллапинин

6. НЕМЕДИКАМЕНТОЗНАЯ ТЕРАПИЯ ДЛЯ ДАННОГО ПАЦИЕНТА ЭТО

1) аблация атрио-вентрикулярного узла

2) имплантация ресинхронизирующего устройства 
3) ЧКВ

4) имплантация кардиостимулятора

5) радиочастотная аблация левого предсердия

6) никакое дополнительное лечение не требуется

\section{Задача 14}

Пациентка $\Phi, 68$ лет 10 лет страдает артериальной гипертензией. У нее нет сахарного диабета. Никакие препараты ранее не принимала. Сегодня вечером отметила появление впервые в жизни интенсивной загрудинной боли в покое, длительностью около 40 минут, в сочетании с интенсивной инспираторной одышкой и сердцебиением. БСМП доставлена в отделение кардиологии. При осмотре: лежит низко, кожа бледная. АД 88/49 мм рт.ст. Левая граница сердца совпадает с верхушечным толчком и расположена на 1,5 см кнаружи от левой СКЛ. ЧСС 128 в 1 минуту, мерцательная аритмия. При аускультации сердца - акцент 2 тона на легочном стволе, систолический шум на верхушке сердца, на мечевидном отростке. В легких везикулярное дыхание, хрипов нет. Отеков нет. На ЭКГ - мерцательная аритмия, депрессия сегмента ST I, AVL, V1-V6.

1. У ДАННОЙ ПАЦИЕНТКИ ИМЕЕТСЯ СЛЕДУЮЩАЯ ФОРМА МЕРЦАТЕЛЬНОЙ АРИТМИИ
1) пароксизмальная
2) персистирующая
3) длительно персистирующая
4) постоянная
5) впервые выявленная

2. ТАКЖЕ У ДАННОЙ ПАЦИЕНТКИ НЕОБХОДИМ ДИФФЕРЕНЦИАЛЬНЫ ДИАГНОЗ МЕЖДУ
1) XCH HIIA IIФK
2) XCH HIII IФK
3) острой декомпенсированной сердечной недостаточностью
4) кардиогенным шоком
5) аритмическим шоком

3. К РАЗВИТИЮ ДАННЫХ ОСЛОЖНЕНИЙ МОГЛИ ПРИВЕСТИ
1) острый коронарный синдром с подъемом сегмента ST
2) острый коронарный синдром без подъема сегмента ST
3) острая почечная недостаточность
4) $\mathrm{XCH}$
5) мерцательная аритмия (как основное заболевание) 
4. В ПЕРВУЮ ОЧЕРЕДЬ ДАННОЙ ПАЦИЕНТКЕ НЕОБХОДИМО
1) выполнить ангиографию
2) определить тропонины и/или КФК-МВ
3) восстановить синусовый ритм
4) снизить ЧСС
5) провести тромболизис
6) начать интрааортальную балонную контрпульсацию

\section{5. ДАННОЙ ПАЦИЕНТКЕ ПОКАЗАНО}
1) немедленное выполнение медикаментозной кардиоверсии
2) немедленное выполнение электрической кардиоверсии
3) 4-недельная антикоагулянтная терапия с последующей кар- диоверсией
4) контроль ЧСС
5) контроль ритма

6. В КАЧЕСТВЕ АНТИКОАГУЛЯНТА В НАСТОЯЩЕЕ ВРЕМЯ НЕОБХОДИМО ИСПОЛЬЗОВАТЬ
1) нефракционированный гепарин
2) эноксапарин
3) фондапаринукс
4) варфарин
5) дабигатран
6) ривароксабан

7. В КАЧЕСТВЕ АНТИАРИТМИЧЕСКОГО ПРЕПАРАТА, У ДАННОЙ ПАЦИЕНТКИ В НАСТОЯЩЕЕ ВРЕМЯ ПОКАЗАНО ПРИМЕНЕНИЕ
1) дигоксина
2) бета-блокаторов
3) амиодарона
4) соталола
5) пропафенона
6) аллапинина

\section{Задача 15}

Мужчина Щ, 68 лет. В течение 5 лет страдает артериальной гипертензией. У него имеется сахарный диабет 2 типа. В анамнезе - перенесенный инфаркт миокарда 2 годами ранее, наследственная отягощенность: мать пациента умерла от инсульта в возрасте 52 лет. В течение последнего года отмечает появление одышки при умеренной нагрузке. Других 
симптомов нет. В последние 1,5-2 месяца эпизодически отмечает появление отеков на нижних конечностях. Регулярно принимает амлодипин 5 мг в сутки, аспирин 125 мг в сутки, аторвастатин 20 мг в сутки. В поликлинике во время профилактического осмотра на ЭКГ выявлена мерцательная аритмия, и пациент направлен в отделение кардиологии. На ЭКГ от предыдущего осмотра (полгода назад) - синусовый ритм. При осмотре: АД 130/78 мм рт.ст. Левая граница сердца совпадает с верхушечным толчком и расположена на 2 см кнаружи от левой СКЛ. ЧСС 78 в 1 минуту, ритм синусовый. При аускультации сердца - акцент 2 тона на легочном стволе, систолический шум на верхушке сердца. В легких везикулярное дыхание, хрипов нет. Отеков нет. На ЭКГ - мерцательная аритмия, патологический Q в II, III, AVF, депрессия ST I, AVL, V5-V6.

\section{1. У ДАННОГО ПАЦИЕНТА ИМЕЕТСЯ СЛЕДУЮЩАЯ ФОРМА} МЕРЦАТЕЛЬНОЙ АРИТМИИ
1) пароксизмальная
2) персистирующая
3) длительно персистирующая
4) постоянная
5) впервые выявленная

2. ИЗ ПЕРЕЧИСЛЕННОГО, В ПЕРВУЮ ОЧЕРЕДЬ ДАННОМУ ПАЦИЕНТУ ПОКАЗАНО ВЫПОЛНЕНИЕ
1) трансторакальной ДЭХОКГ
2) чреспищеводной ДЭХОКГ
3) рентгенографии органов грудной клетки
4) холтеровского мониторирования
5) пробы с физической нагрузкой
6) коронарография

\section{3. ДАННОМУ ПАЦИЕНТУ ПОКАЗАНО}

1) немедленное выполнение медикаментозной кардиоверсии

2) немедленное выполнение электрической кардиоверсии

3) при наличии тромбов в полостях сердца: 3-недельная терапия ОАК с повторным исследование и возможной последующей кардиоверсией

4) при отсутствии тромбов в полостях сердца: гепарин и кардиоверсия

5) контроль ЧСС 
4. В КАЧЕСТВЕ ДЛИТЕЛЬНОЙ АНТИТРОМБОТИЧЕСКОЙ ТЕРАПИИ ДАННОМУ ПАЦИЕНТУ МОГУТ БЫТЬ НАЗНАЧЕНЫ СЛЕДУЮЩИЕ ВАРИАНТЫ ТЕРАПИИ
1) аспирин
2) клопидогрель
3) тикагрелор
4) варфарин
5) дабигатран
6) ривароксабан
7) апиксабан

5. НЕМЕДИКАМЕНТОЗНАЯ ТЕРАПИЯ ДЛЯ ДАННОГО ПАЦИЕНТА ЭТО
1) аблация атрио-вентрикулярного узла
2) имплантация ресихронизирующего устройства
3) ЧКВ
4) имплантация кардиостимулятора
5) радиочастотная аблация левого предсердия
6) никакое дополнительное лечение не требуется

\section{Задача 16}

Пациент A, 25 лет в течение 2 лет отмечает эпизоды сердцебиения. При обследовании выявлена связь сердцебиения с появлением мерцательной аритмии. У него нет сахарного диабета. Физическую нагрузку переносит адекватно. Иногда принимает кордарон 200 мг (при частых приступах). Другие антиаритмики ранее не принимал. Обратился к кардиологу в связи с тем, что эпизоды сердцебиения стали частыми, до 2-3 раз в неделю, что сопровождается слабостью, снижением толерантности к физической нагрузке, а также неприятными ощущениями «переворачивания» сердца. Купируются данные эпизоды самостоятельно. При осмотре: ИМТ 26 кг/м², АД 120/80 мм рт.ст. Левая граница сердца совпадает с верхушечным толчком и расположена на 1,5 см кнутри от левой СКЛ. ЧСС 78 в 1 минуту, синусовый ритм. При аускультации сердца - слабый систолический шум на верхушке. В легких везикулярное дыхание, хрипов нет. Отеков нет. На ЭКГ - синусовый ритм с ЧСС 76 в 1 мин, с-м WPW.

\section{1. У ДАННОГО ПАЦИЕНТА ИМЕЕТСЯ СЛЕДУЮЩАЯ ФОРМА МЕРЦАТЕЛЬНОЙ АРИТМИИ \\ 1) пароксизмальная \\ 2) персистирующая}



3) длительно персистирующая
4) постоянная
5) впервые выявленная

2. ИЗ ПЕРЕЧИСЛЕННОГО, ДАННОМУ ПАЦИЕНТУ ПОКАЗАНО ВЫПОЛНЕНИЕ
1) трансторакальной ДЭХОКГ
2) чреспищеводной ДЭХОКГ
3) рентгенографии органов грудной клетки
4) холтеровского мониторирования
5) пробы с физической нагрузкой
6) коронарография

\section{3. ДАННОМУ ПАЦИЕНТУ ПОКАЗАНО}

1) тактика - контроль ЧСС

2) тактика - контроль ритма

3) подбор медикаментозной антиаритмической терапии

4) немедленное выполнение радиочастотной катетерной абляции

5) выполнение радиочастотной катетерной абляции при невозможности подобрать адекватную антиаритмическую терапию

4. В КАЧЕСТВЕ АНТИТРОМБОТИЧЕСКОЙ ТЕРАПИИ ДАННОМУ ПАЦИЕНТУ МОГУТ БЫТЬ НАЗНАЧЕНЫ СЛЕДУЮЩИЕ ВАРИАНТЫ ТЕРАПИИ
1) аспирин
2) клопидогрель
3) тикагрелор
4) варфарин
5) дабигатран
6) ривароксабан
7) апиксабан

5. В КАЧЕСТВЕ АНТИАРИТМИЧЕСКОГО ПРЕПАРАТА, У ДАННОГО ПАЦИЕНТА В НАСТОЯЩЕЕ ВРЕМЯ ПОКАЗАНО ПРИМЕНЕНИЕ
1) дигоксин
2) бета-блокаторы
3) амиодарон
4) соталол
5) пропафенон
6) аллапинин 
6. ВОЗМОЖНАЯ НЕМЕДИКАМЕНТОЗНАЯ ТЕРАПИЯ ДЛЯ ДАННОГО ПАЦИЕНТА ЭТО
1) аблация атрио-вентрикулярного узла
2) имплантация СРТ
3) ЧКВ
4) имплантация кардиостимулятора
5) радиочастотная аблация левого предсердия
6) никакое дополнительное лечение не требуется

\section{Задача 17}

Пациентка $\Phi, 68$ лет 10 лет страдает артериальной гипертензией. У нее нет сахарного диабета, ИБС, но имеются проявления деформирующего остеоартроза коленных суставов и наследственная отягощенность: отец пациентки умер от инфаркта в возрасте 52 лет. Никакие препараты ранее не принимала. В течение последнего года отмечает появление одышки инспираторного характера при умеренной физической нагрузке, купирующейся в покое. Других симптомов нет. При осмотре: ИМТ 32 кг/м², офисное АД 168/102 мм рт.ст., Левая граница сердца совпадает с верхушечным толчком и расположена на 1,5 см кнаружи от левой СКЛ. ЧСС 78 в 1 минуту, ритм правильный. При аускультации сердца - акцент 2 тона на аорте, систолический шум на верхушке. В легких везикулярное дыхание, хрипов нет. Отеков нет.

\section{1. У ДАННОЙ ПАЦИЕНТКИ ИМЕЕТСЯ}
1) $\mathrm{XCH} \mathrm{HI} \mathrm{I} \mathrm{ФK}$
2) XCH HIIA II $\Phi \mathrm{K}$
3) $\mathrm{XCH}$ HIII I $\Phi \mathrm{K}$
4) острая декомпенсированная сердечная недостаточность
5) отек легких

2. В ПЕРВУЮ ОЧЕРЕДЬ ДАННОЙ ПАЦИЕНТКЕ ПОКАЗАНО ВЫПОЛНЕНИЕ (ИЗ ПЕРЕЧИСЛЕННОГО)
1) ЭКГ
2) ДЭХОКГ
3) рентгенография органов грудной клетки
4) холтеровское мониторирование
5) холестерин, ЛПНП, ЛПВП, ТАГ
6) БНП/NT-проБНП 
3. СТАРТОВОЙ ТЕРАПИЕЙ ДЛЯ ДАННОЙ ПАЦИЕНТКИ МОГУТ БЫТЬ

1) ингибитор АПФ

2) ингибитор АПФ в комбинации с антагонистом кальция

3) ингибитор АПФ в комбинации с тиазидным диуретиком

4) бета-блокатор в комбинации с ингибитором АПФ

5) антагонист кальция

6) тиазидный диуретик

Получены результаты дополнительных обследований пациентки. Наиболее значимые: на ЭКГ - синусовый ритм с ЧСС 75 в 1, ЭОС отклонена влево. Признаки гипертрофии ЛЖ. В Холестерин - 6,8 ммоль/л, ЛПНП - 4,1 ммоль/л, ТАГ 1,3 ммоль/л, СКФ $=51$ мл/мин/1,73 м², при ДЭХОКГ - клапанной патологии не выявлено, зон гипо-акинезии не выявлено, ФВ $=48 \%$.

4. ПАЦИЕНТКЕ ОБЯЗАТЕЛЬНО НЕОБХОДИМО НАЗНАЧИТЬ
1) антагонист альдостерона
2) аспирин
3) статины
4) нитраты
5) петлевые диуретики
6) дигоксин

5. НЕОБХОДИМО ПРОВЕСТИ ДИНАМИЧЕСКОЕ НАБЛЮДЕНИЕ ЗА ПАЦИЕНТКОЙ, И ПРИ СОХРАНЕНИИ СИМПТОМОВ СЕРДЕЧНОЙ НЕДОСТАТОЧНОСТИ (ОДЫШКА, ПОЯВЛЕНИЕ ОТЕКОВ) ВОЗМОЖНО ДОПОЛНИТЕЛЬНОЕ НАЗНАЧЕНИЕ
1) антагонист альдостерона
2) ингибитор АПФ
3) нитраты
4) петлевые диуретики
5) дигоксин
6) бета-блокатор

\section{Задача 18}

Пациент А, 68 лет В течение 10 лет страдает постоянной мерцательной аритмией. У него нет сахарного диабета. В анамнезе - перенесенный ишемический инсульт 2 годами ранее. В течение последних 5 лет года отмечает появление одышки при небольшой нагрузке. В последние 
1,5-2 месяца эпизодически отмечает появление отеков на нижних конечностях. Регулярно принимает эналаприл 5 мг 2 раза в сутки. При осмотре: ИМТ 36 кг/м², офисное АД 120/80 мм рт.ст. Левая граница сердца совпадает с верхушечным толчком и расположена на 1,5 см кнаружи от левой СКЛ. ЧСС 108 в 1 минуту, мерцательная аритмия. При аускультации сердца - акцент 2 тона на аорте, систолический шум на верхушке сердца. В легких везикулярное дыхание, небольшое количество влажных незвучных мелкопузырчатых хрипов в нижних отделах легких с 2-х сторон. Отеков нет. Уровень общего холестерина - 3,2 ммоль/л, СКФ $=39$ мл/мин $/ 1,73$ м². На ЭКГ - мерцательная аритмия. Отклонение электрической оси влево. При ДЭХОКГ - клапанной патологии не выявлено, зон гипо-акинезии не выявлено. ФВ $68 \%$. Какое осложнение имеется у данного пациента?

1. У ДАННОГО ПАЦИЕНТА ИМЕЕТСЯ
1) XCH HI I ФK
2) XCH HIIA II $\Phi$ K
3) $\mathrm{XCH}$ HIIB III $\Phi \mathrm{K}$
4) острая декомпенсированная сердечная недостаточность
5) отек легких

2. В НАСТОЯЩЕЕ ВРЕМЯ ДАННОМУ ПАЦИЕНТУ ПОКАЗАНО ВЫПОЛНЕНИЕ (ИЗ ПЕРЕЧИСЛЕННОГО)
1) чреспищеводной ДЭХОКГ
2) рентгенографии органов грудной клетки
3) холтеровского мониторирования
4) ЛПНП, ЛПВП, ТАГ
5) БНП/NT-проБНП

\section{3. ДАННОМУ ПАЦИЕНТУ ПОКАЗАНО}
1) тактика - контроль ЧСС
2) тактика - контроль ритма
3) подбор медикаментозной антиаритмической терапии
4) немедленное выполнение радиочастотной катетерной абляции
5) выполнение радиочастотной катетерной абляции при невоз- можности подобрать адекватную антиаритмическую терапию

4. ДАННОМУ ПАЦИЕНТУ ПОКАЗАНО НАЗНАЧЕНИЕ СЛЕДУЮЩИХ АНТИАРИТМИЧЕСКИХ ПРЕПАРАТОВ (ИЗ ПЕРЕЧИСЛЕННОГО)
1) амиодарон
2) пропафенон 

3) метопролол
4) дигоксин
5) новокаинамид
6) соталол

5. ТАКЖЕ ДАННОМУ ПАЦИЕНТУ ПОКАЗАНО НАЗНАЧЕНИЕ СЛЕДУЮЩИХ
1) верошпирон
2) фуросемид
3) нитросорбид
4) амлодипин
5) ивабрадин

6. В КАЧЕСТВЕ АНТИТРОМБОТИЧЕСКОЙ ТЕРАПИИ ДАННОМУ ПАЦИЕНТУ МОГУТ БЫТЬ НАЗНАЧЕНЫ СЛЕДУЮЩИЕ ВАРИАНТЫ ТЕРАПИИ
1) аспирин
2) клопидогрель
3) тикагрелор
4) варфарин
5) дабигатран
6) ривароксабан
7) апиксабан

\section{Задача 19}

Пациент К, 65 лет в течение 45 лет артериальной гипертензией, и в течение 25 лет - ИБС. В анамнезе - 3 перенесенных инфаркта миокарда, последний - 2 года назад. У него нет сахарного диабета. В течение последних 10 лет отмечает появление одышки при небольшой нагрузке, эпизодически - отеков нижних конечностей. 2 месяца назад, во время госпитализации по поводу декомпенсации сердечной недостаточности имел место эпизод фибрилляции желудочков, с успешной кардиоверсией. В настоящее время - одышка при небольшой нагрузке. Регулярно принимает эналаприл 5 мг 2 раза в сутки, кордарон 200 мг в сутки, бисопролол 2,5 мг в сутки, аспирин 125 мг в сутки, верошпирон 100 мг в сутки. При осмотре на плановом приеме: ИМТ 36 кг/м², АД 110/68 мм рт.ст. Левая граница сердца совпадает с верхушечным толчком и расположена на 2 см кнаружи от левой СКЛ. ЧСС 78 в 1 минуту, ритм синусовый. При аускультации сердца - акцент 2 тона на аорте, систолический шум на верхушке сердца, на мечевидном отростке. В легких везикулярное дыха- 
ние, небольшое количество влажных незвучных мелкопузырчатых хрипов в нижних отделах легких с 2-х сторон. Отеков нет. Уровень общего холестерина - 3,2 ммоль/л, ЛПНП - 2,1 ммоль/л, СКФ $=41$ мл/мин/1,73 м². Других значимых отклонений нет. На ЭКГ - синусовый ритм, рубцовые изменения в переднее-перегородочно-верхушечно-боковой области. При ДЭХОКГ - клапанной патологии не выявлено, митральная и трикуспидальная регургитация умеренной степени, зоны гипо-акинезии в передней стенке и перегородке, умеренная дилатация полостей ЛЖ, ПЖ., ФВ $35 \%$.

\section{1. У ДАННОГО ПАЦИЕНТА ИМЕЕТСЯ}
1) XCH HI I ФK
2) XCH HIIA II $\Phi K$
3) XCH HIIB III ФK
4) острая декомпенсированная сердечная недостаточность
5) отек легких

2. В НАСТОЯЩЕЕ ВРЕМЯ ДАННОМУ ПАЦИЕНТУ ПОКАЗАНО ВЫПОЛНЕНИЕ (ИЗ ПЕРЕЧИСЛЕННОГО)
1) чреспищеводной ДЭХОКГ
2) рентгенографии органов грудной клетки
3) холтеровского мониторирования
4) ЛПНП, ЛПВП, ТАГ
5) БНП/NT-проБНП

3. ДАННОМУ ПАЦИЕНТУ ПОКАЗАН ПРИЕМ СЛЕДУЮЩИХ АНТИАРИТМИЧЕСКИХ ПРЕПАРАТОВ (ИЗ ПЕРЕЧИСЛЕННОГО)
1) амиодарон
2) пропафенон
3) бисопролол
4) дигоксин
5) новокаинамид
6) соталол

4. ТАКЖЕ ДАННОМУ ПАЦИЕНТУ ПОКАЗАНО НАЗНАЧЕНИЕ СЛЕДУЮЩИХ ПРЕПАРАТОВ
1) верошпирон
2) фуросемид
3) нитросорбид
4) амлодипин 
5) ивабрадин

6) аторвастатин

5. В КАЧЕСТВЕ АНТИТРОМБОТИЧЕСКОЙ ТЕРАПИИ ДАННОМУ ПАЦИЕНТУ НЕОБХОДИМ
1) аспирин
2) клопидогрель
3) аспирин + клопидогрель
4) тикагрелор
5) варфарин
6) дабигатран
7) ривароксабан

\section{6. ВОЗМОЖНАЯ НЕМЕДИКАМЕНТОЗНАЯ ТЕРАПИЯ ДЛЯ ДАН- НОГО ПАЦИЕНТА ЭТО \\ 1) имплантация ресинхронизирующего устройства \\ 2) имплантация дефибриллатора-кардиовертера \\ 3) ЧКВ \\ 4) имплантация кардиостимулятора \\ 5) радиочастотная аблация левого предсердия \\ 6) никакое дополнительное лечение не требуется}

\section{Задача 20}

Пациент $Ф, 71$ год в течение 47 лет страдает артериальной гипертензией, и в течение 25 лет - ИБС. В анамнезе - 3 перенесенных инфаркта миокарда, последний 2 года назад. У него нет сахарного диабета. В течение последних 10 лет года отмечает появление одышки при небольшой нагрузке, эпизодически - отеков нижних конечностей. Отмечает частые (3-4 раза в год) декомпенсации сердечной недостаточности в виде появления одышки в покое, и в горизонтальном положении, снижение толерантности к физической нагрузке, появления выраженных отеков. В настоящее время - одышка при небольшой нагрузке. Регулярно принимает эналаприл 5 мг 2 раза в сутки, карведилол 12,5 мг 2 раза в сутки, аспирин 125 мг в сутки, фуросемид 20 мг в сутки, верошпирон - 50 мг в сутки.

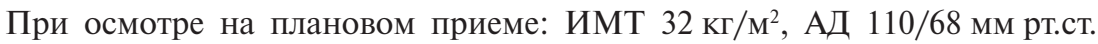
Левая граница сердца совпадает с верхушечным толчком и расположена на 2 см кнаружи от левой СКЛ. ЧСС 98 в 1 минуту, ритм синусовый. При аускультации сердца - акцент 2 тона на аорте, систолический шум на верхушке сердца, на мечевидном отростке. В легких везикулярное дыхание, небольшое количество влажных незвучных мелкопузырчатых 
хрипов в нижних отделах легких с 2-х сторон. Отеков нет. Уровень общего холестерина - 3,8 ммоль/л, ЛПНП - 2,6 ммоль/л, СКФ $=41$ мл/мин/1,73 м². Других значимых отклонений нет. На ЭКГ - синусовый ритм, ПБЛНПГ, $\mathrm{QRS}=125$ мс. При ДЭХОКГ - клапанной патологии не выявлено, митральная и трикуспидальная регургитация тяжелой степени, зоны гипо-акинезии в передней стенке и перегородке, значительная дилатация полостей ЛЖ, ЛП, умеренная дилатация - ПЖ, ПП, ФВ $27 \%$, декомпенсация кровообращения по обоим кругам.

\section{1. У ДАННОГО ПАЦИЕНТА ИМЕЕТСЯ}
1) $\mathrm{XCH}$ HI I ФK
2) XCH HIIA II $\Phi$ K
3) XCH HIIB III ФK
4) острая декомпенсированная сердечная недостаточность
5) отек легких

2. В НАСТОЯЩЕЕ ВРЕМЯ ДАННОМУ ПАЦИЕНТУ ПОКАЗАНО ВЫПОЛНЕНИЕ (ИЗ ПЕРЕЧИСЛЕННОГО)
1) чреспищеводной ДЭХОКГ
2) рентгенографии органов грудной клетки
3) холтеровского мониторирования
4) ЛПНП, ЛПВП, ТАГ
5) БНП/NT-проБНП

3. ПРОВОДИМУЮ В НАСТОЯЩЕЕ ВРЕМЯ ТЕРАПИЮ НЕОБХОДИМО ИЗМЕНИТЬ СЛЕДУЮЩИМ ОБРАЗОМ
1) отменить верошпирон
2) увеличить дозу фуросемида
3) назначить нитросорбид
4) увеличить дозу карведилола
5) назначить ивабрадин
6) назначить аторвастатин

4. В КАЧЕСТВЕ АНТИТРОМБОТИЧЕСКОЙ ТЕРАПИИ ДАННОМУ ПАЦИЕНТУ НЕОБХОДИМ
1) аспирин
2) клопидогрель
3) аспирин + клопидогрель 

4) тикагрелор
5) варфарин
6) дабигатран
7) ривароксабан

5. ВОЗМОЖНАЯ НЕМЕДИКАМЕНТОЗНАЯ ТЕРАПИЯ ДЛЯ ДАННОГО ПАЦИЕНТА ЭТО

1) имплантация ресинхронизирующего устройства

2) имплантация дефибриллатора-кардиовертера

3) ЧКВ

4) имплантация кардиостимулятора

5) радиочастотная аблация левого предсердия

6) никакое дополнительное лечение не требуется 


\section{ЭТАЯОНЫ ОТВЕТОВ К ТЕСТОВЫМ ЗАДАНИЯМ}

\begin{tabular}{|c|c|c|c|c|c|}
\hline $\begin{array}{c}\text { Номер } \\
\text { вопроса }\end{array}$ & $\begin{array}{c}\text { Правильный } \\
\text { ответ }\end{array}$ & $\begin{array}{c}\text { Номер } \\
\text { вопроса }\end{array}$ & $\begin{array}{c}\text { Правильный } \\
\text { ответ }\end{array}$ & $\begin{array}{c}\text { Номер } \\
\text { вопроса }\end{array}$ & $\begin{array}{c}\text { Правильный } \\
\text { ответ }\end{array}$ \\
\hline 1 & 4 & 25 & 1,3 & 49 & 1,5 \\
\hline 2 & $1,3,4,6$ & 26 & 1,3 & 50 & 2,4 \\
\hline 3 & 1,5 & 27 & 3 & 51 & $1,2,3,4,5,6$ \\
\hline 4 & 1,3 & 28 & 3 & 52 & 1,4 \\
\hline 5 & 1 & 29 & $2,3,4,5$ & 53 & 1 \\
\hline 6 & 1 & 30 & 4 & 54 & $1,2,3$ \\
\hline 7 & 4 & 31 & $1,2,3,6$ & 55 & 4 \\
\hline 8 & 6 & 32 & 2 & 56 & $1,2,3,4,5,6$ \\
\hline 9 & $1,2,4$ & 33 & 6 & 57 & 2 \\
\hline 10 & $1,2,4,5,6$ & 34 & 2,5 & 58 & 2,4 \\
\hline 11 & 1 & 35 & 1 & 59 & 2 \\
\hline 12 & $1,2,3$ & 36 & 3 & 60 & 3 \\
\hline 13 & 2 & 37 & 3 & 61 & 2 \\
\hline 14 & $1,2,4,6$ & 38 & $1,2,3,4$ & 62 & $2,3,5$ \\
\hline 15 & 2 & 39 & 1,2 & 63 & 2,6 \\
\hline 16 & 2 & 40 & $3,4,5,6,7$ & 64 & 2 \\
\hline 17 & 3 & 41 & 2,6 & 65 & $3,4,5$ \\
\hline 18 & 4 & 42 & $1,2,3,5$ & 66 & 3 \\
\hline 19 & 2 & 43 & $1,2,3,4$ & 67 & $1,3,4,5$ \\
\hline 20 & 3 & 44 & 1 & 68 & $1,2,3,4$ \\
\hline 21 & $1,2,3,4,6$ & 45 & $1,2,3,4,5,6$ & 69 & 2 \\
\hline 22 & $1,3,4$ & 46 & 2 & 70 & 1,3 \\
\hline 23 & 4 & 47 & $1,2,3,6$ & 71 & $2,4,5,6$ \\
\hline 24 & 4,5 & 48 & 1,3 & 72 & 1,2 \\
\hline 73 & 2 & 102 & 1 & 131 & 4,5 \\
\hline 74 & 2 & 103 & $1,4,5,6$ & 132 & $1,3,4,5,6$ \\
\hline
\end{tabular}




\begin{tabular}{|c|c|c|c|c|c|}
\hline $\begin{array}{c}\text { Номер } \\
\text { вопроса }\end{array}$ & $\begin{array}{c}\text { Правильный } \\
\text { ответ }\end{array}$ & $\begin{array}{c}\text { Номер } \\
\text { вопроса }\end{array}$ & $\begin{array}{c}\text { Правильный } \\
\text { ответ }\end{array}$ & $\begin{array}{c}\text { Номер } \\
\text { вопроса }\end{array}$ & $\begin{array}{c}\text { Правильный } \\
\text { ответ }\end{array}$ \\
\hline 75 & 2,5 & 104 & $1,4,5$ & 133 & $1,3,4$ \\
\hline 76 & $2,3,5,6$ & 105 & $1,3,4,5,6,7$ & 134 & $1,2,3,4,6$ \\
\hline 77 & 1 & 106 & 1 & 135 & 3,4 \\
\hline 78 & 3 & 107 & $1,3,4,5$ & 136 & $1,3,4$ \\
\hline 79 & $1,4,5$ & 108 & 3,5 & 137 & $1,3,4,5$ \\
\hline 80 & $1,4,6$ & 109 & 4 & 138 & $2,3,4,5$ \\
\hline 81 & $1,4,5$ & 110 & 5 & 139 & 3 \\
\hline 82 & $3,4,5$ & 111 & 3 & 140 & 1 \\
\hline 83 & 1,2 & 112 & 4 & 141 & 2 \\
\hline 84 & 2 & 113 & 1 & 142 & 1 \\
\hline 85 & 2 & 114 & 2 & 143 & 1,4 \\
\hline 86 & $2,3,4,5$ & 115 & $2,3,4,5$ & 144 & 2,3 \\
\hline 87 & $1,2,4,6$ & 116 & 2 & 145 & $2,3,4,6$ \\
\hline 88 & $1,4,5,6$ & 117 & $3,4,5,6$ & 146 & $1,3,4$ \\
\hline 89 & 1 & 118 & $2,3,4$ & 147 & $2,3,5$ \\
\hline 90 & $1,2,3,4,5$ & 119 & 4,5 & 148 & $1,2,3,4$ \\
\hline 91 & 4 & 120 & 1 & 149 & 1,2 \\
\hline 92 & 2,3 & 121 & 2,4 & 150 & $1,2,3,5,6,7,8$ \\
\hline 93 & $1,2,4$ & 122 & $1,3,5$ & & \\
\hline 94 & 1 & 123 & $2,3,4$ & & \\
\hline 95 & 1 & 124 & 1 & & \\
\hline 96 & 2 & 125 & 3 & & \\
\hline 97 & 1 & 126 & 6 & & \\
\hline 98 & 5 & 127 & 1 & & \\
\hline 99 & $1,2,3,5,6,7,8$ & 128 & 1 & & \\
\hline 100 & 1 & 129 & 1 & & \\
\hline 101 & 2 & 130 & 2 & & \\
\hline
\end{tabular}




\section{ЭТАЯОНЫ ОТВЕТОВ К ЗАДАЧАМ}

\section{Задача 1}

\begin{tabular}{|c|c|c|c|c|c|}
\hline $\begin{array}{c}\text { Номер } \\
\text { вопроса }\end{array}$ & $\begin{array}{c}\text { Правильный } \\
\text { ответ }\end{array}$ & $\begin{array}{c}\text { Номер } \\
\text { вопроса }\end{array}$ & $\begin{array}{c}\text { Правильный } \\
\text { ответ }\end{array}$ & $\begin{array}{c}\text { Номер } \\
\text { вопроса }\end{array}$ & $\begin{array}{c}\text { Правильный } \\
\text { ответ }\end{array}$ \\
\hline $\mathbf{1}$ & 4 & $\mathbf{4}$ & 3 & $\mathbf{7}$ & 1,3 \\
\hline $\mathbf{2}$ & 4 & $\mathbf{5}$ & 2 & & \\
\hline $\mathbf{3}$ & $1,3,4,5$ & $\mathbf{6}$ & 2,3 & & \\
\hline
\end{tabular}

\section{Задача 2}

\begin{tabular}{|c|c|c|c|c|c|}
\hline $\begin{array}{c}\text { Номер } \\
\text { вопроса }\end{array}$ & $\begin{array}{c}\text { Правильный } \\
\text { ответ }\end{array}$ & $\begin{array}{c}\text { Номер } \\
\text { вопроса }\end{array}$ & $\begin{array}{c}\text { Правильный } \\
\text { ответ }\end{array}$ & $\begin{array}{c}\text { Номер } \\
\text { Вопроса }\end{array}$ & $\begin{array}{c}\text { Правильный } \\
\text { ответ }\end{array}$ \\
\hline $\mathbf{1}$ & 6 & $\mathbf{4}$ & 4 & $\mathbf{7}$ & 1,3 \\
\hline $\mathbf{2}$ & 4 & $\mathbf{5}$ & 4 & & \\
\hline $\mathbf{3}$ & $2,3,4,5,6$ & $\mathbf{6}$ & 2,3 & & \\
\hline
\end{tabular}

\section{Задача 3}

\begin{tabular}{|c|c|c|c|}
\hline $\begin{array}{c}\text { Номер } \\
\text { вопроса }\end{array}$ & $\begin{array}{c}\text { Правильный } \\
\text { ответ }\end{array}$ & $\begin{array}{c}\text { Номер } \\
\text { вопроса }\end{array}$ & $\begin{array}{c}\text { Правильный } \\
\text { ответ }\end{array}$ \\
\hline $\mathbf{1}$ & 4 & $\mathbf{4}$ & 4 \\
\hline $\mathbf{2}$ & 4 & $\mathbf{5}$ & 1 \\
\hline $\mathbf{3}$ & $1,2,3$ & & \\
\hline
\end{tabular}

\section{Задача 4}

\begin{tabular}{|c|c|c|c|c|c|}
\hline $\begin{array}{c}\text { Номер } \\
\text { вопроса }\end{array}$ & $\begin{array}{c}\text { Правильный } \\
\text { ответ }\end{array}$ & $\begin{array}{c}\text { Номер } \\
\text { вопроса }\end{array}$ & $\begin{array}{c}\text { Правильный } \\
\text { ответ }\end{array}$ & $\begin{array}{c}\text { Номер } \\
\text { Вопроса }\end{array}$ & $\begin{array}{c}\text { Правильный } \\
\text { ответ }\end{array}$ \\
\hline $\mathbf{1}$ & 3 & $\mathbf{4}$ & $1,3,5$ & $\mathbf{7}$ & 1 \\
\hline $\mathbf{2}$ & 4 & $\mathbf{5}$ & $1,2,4$ & & \\
\hline $\mathbf{3}$ & $2,4,5,6$ & $\mathbf{6}$ & 2,6 & & \\
\hline
\end{tabular}

\section{Задача 5}

\begin{tabular}{|c|c|c|c|c|c|}
\hline $\begin{array}{c}\text { Номер } \\
\text { вопроса }\end{array}$ & $\begin{array}{c}\text { Правильный } \\
\text { ответ }\end{array}$ & $\begin{array}{c}\text { Номер } \\
\text { вопроса }\end{array}$ & $\begin{array}{c}\text { Правильный } \\
\text { ответ }\end{array}$ & $\begin{array}{c}\text { Номер } \\
\text { Вопроса }\end{array}$ & $\begin{array}{c}\text { Правильный } \\
\text { ответ }\end{array}$ \\
\hline $\mathbf{1}$ & 5 & $\mathbf{4}$ & $1,3,5$ & $\mathbf{7}$ & 2,5 \\
\hline $\mathbf{2}$ & 4,5 & $\mathbf{5}$ & 4 & $\mathbf{8}$ & 5 \\
\hline $\mathbf{3}$ & $2,4,5,6$ & $\mathbf{6}$ & $1,3,6$ & & \\
\hline
\end{tabular}




\section{Задача 6}

\begin{tabular}{|c|c|c|c|c|c|}
\hline $\begin{array}{c}\text { Номер } \\
\text { вопроса }\end{array}$ & $\begin{array}{c}\text { Правильный } \\
\text { ответ }\end{array}$ & $\begin{array}{c}\text { Номер } \\
\text { вопроса }\end{array}$ & $\begin{array}{c}\text { Правильный } \\
\text { ответ }\end{array}$ & $\begin{array}{c}\text { Номер } \\
\text { Вопроса }\end{array}$ & $\begin{array}{c}\text { Правильный } \\
\text { ответ }\end{array}$ \\
\hline $\mathbf{1}$ & 4 & $\mathbf{4}$ & $1,3,5,6$ & $\mathbf{7}$ & 4 \\
\hline $\mathbf{2}$ & 4 & $\mathbf{5}$ & 1,4 & & \\
\hline $\mathbf{3}$ & $2,3,4,5$ & $\mathbf{6}$ & 2,6 & & \\
\hline
\end{tabular}

\section{Задача 7}

\begin{tabular}{|c|c|c|c|c|c|}
\hline $\begin{array}{c}\text { Номер } \\
\text { вопроса }\end{array}$ & $\begin{array}{c}\text { Правильный } \\
\text { ответ }\end{array}$ & $\begin{array}{c}\text { Номер } \\
\text { вопроса }\end{array}$ & $\begin{array}{c}\text { Правильный } \\
\text { ответ }\end{array}$ & $\begin{array}{c}\text { Номер } \\
\text { Вопроса }\end{array}$ & $\begin{array}{c}\text { Правильный } \\
\text { ответ }\end{array}$ \\
\hline $\mathbf{1}$ & 4 & $\mathbf{4}$ & 2 & 7 & 2,6 \\
\hline $\mathbf{2}$ & 5 & $\mathbf{5}$ & 5 & & \\
\hline $\mathbf{3}$ & $2,3,4,5$ & $\mathbf{6}$ & 4 & & \\
\hline
\end{tabular}

\section{Задача 8}

\begin{tabular}{|c|c|c|c|c|c|}
\hline $\begin{array}{c}\text { Номер } \\
\text { вопроса }\end{array}$ & $\begin{array}{c}\text { Правильный } \\
\text { ответ }\end{array}$ & $\begin{array}{c}\text { Номер } \\
\text { вопроса }\end{array}$ & $\begin{array}{c}\text { Правильный } \\
\text { ответ }\end{array}$ & $\begin{array}{c}\text { Номер } \\
\text { Вопроса }\end{array}$ & $\begin{array}{c}\text { Правильный } \\
\text { ответ }\end{array}$ \\
\hline $\mathbf{1}$ & 3 & $\mathbf{4}$ & 1,3 & $\mathbf{7}$ & 4 \\
\hline $\mathbf{2}$ & 1 & $\mathbf{5}$ & 1,4 & & \\
\hline $\mathbf{3}$ & $2,3,4,5$ & $\mathbf{6}$ & 2,5 & & \\
\hline
\end{tabular}

\section{Задача 9}

\begin{tabular}{|c|c|c|c|}
\hline $\begin{array}{c}\text { Номер } \\
\text { вопроса }\end{array}$ & $\begin{array}{c}\text { Правильный } \\
\text { ответ }\end{array}$ & $\begin{array}{c}\text { Номер } \\
\text { вопроса }\end{array}$ & $\begin{array}{c}\text { Правильный } \\
\text { ответ }\end{array}$ \\
\hline $\mathbf{1}$ & 2 & $\mathbf{4}$ & $1,2,3$ \\
\hline $\mathbf{2}$ & $1,3,5$ & $\mathbf{5}$ & 2,3 \\
\hline $\mathbf{3}$ & 2 & & \\
\hline
\end{tabular}

\section{Задача 10}

\begin{tabular}{|c|c|c|c|}
\hline $\begin{array}{c}\text { Номер } \\
\text { вопроса }\end{array}$ & $\begin{array}{c}\text { Правильный } \\
\text { ответ }\end{array}$ & $\begin{array}{c}\text { Номер } \\
\text { вопроса }\end{array}$ & $\begin{array}{c}\text { Правильный } \\
\text { ответ }\end{array}$ \\
\hline $\mathbf{1}$ & 2 & $\mathbf{4}$ & $1,2,3,4$ \\
\hline $\mathbf{2}$ & $2,4,6$ & $\mathbf{5}$ & 2,5 \\
\hline $\mathbf{3}$ & 2 & & \\
\hline
\end{tabular}


Е.А. Наумова, Ю.Г. Швари, Н.А. Железнякова, О.Н. Семенова

\section{Задача 11}

\begin{tabular}{|c|c|c|c|}
\hline $\begin{array}{c}\text { Номер } \\
\text { вопроса }\end{array}$ & $\begin{array}{c}\text { Правильный } \\
\text { ответ }\end{array}$ & $\begin{array}{c}\text { Номер } \\
\text { вопроса }\end{array}$ & $\begin{array}{c}\text { Правильный } \\
\text { ответ }\end{array}$ \\
\hline $\mathbf{1}$ & 1 & $\mathbf{4}$ & 6 \\
\hline $\mathbf{2}$ & 6 & $\mathbf{5}$ & 2,3 \\
\hline $\mathbf{3}$ & 1 & & \\
\hline
\end{tabular}

Задача 12

\begin{tabular}{|c|c|c|c|}
\hline $\begin{array}{c}\text { Номер } \\
\text { вопроса }\end{array}$ & $\begin{array}{c}\text { Правильный } \\
\text { ответ }\end{array}$ & $\begin{array}{c}\text { Номер } \\
\text { вопроса }\end{array}$ & $\begin{array}{c}\text { Правильный } \\
\text { ответ }\end{array}$ \\
\hline $\mathbf{1}$ & 3 & $\mathbf{4}$ & 6 \\
\hline $\mathbf{2}$ & $3,4,5$ & $\mathbf{5}$ & 3,4 \\
\hline $\mathbf{3}$ & 5 & & \\
\hline
\end{tabular}

Задача 13

\begin{tabular}{|c|c|c|c|}
\hline $\begin{array}{c}\text { Номер } \\
\text { вопроса }\end{array}$ & $\begin{array}{c}\text { Правильный } \\
\text { ответ }\end{array}$ & $\begin{array}{c}\text { Номер } \\
\text { вопроса }\end{array}$ & $\begin{array}{c}\text { Правильный } \\
\text { ответ }\end{array}$ \\
\hline $\mathbf{1}$ & 4 & $\mathbf{4}$ & $4,5,6,7$ \\
\hline $\mathbf{2}$ & 1,4 & $\mathbf{5}$ & 5,6 \\
\hline $\mathbf{3}$ & 4 & $\mathbf{6}$ & 6 \\
\hline
\end{tabular}

\section{Задача 14}

\begin{tabular}{|c|c|c|c|c|c|}
\hline $\begin{array}{c}\text { Номер } \\
\text { вопроса }\end{array}$ & $\begin{array}{c}\text { Правильный } \\
\text { ответ }\end{array}$ & $\begin{array}{c}\text { Номер } \\
\text { вопроса }\end{array}$ & $\begin{array}{c}\text { Правильный } \\
\text { ответ }\end{array}$ & $\begin{array}{c}\text { Номер } \\
\text { Вопроса }\end{array}$ & $\begin{array}{c}\text { Правильный } \\
\text { ответ }\end{array}$ \\
\hline $\mathbf{1}$ & 2 & $\mathbf{4}$ & 4 & $\mathbf{7}$ & 3 \\
\hline $\mathbf{2}$ & 4,5 & $\mathbf{5}$ & 2,5 & & \\
\hline $\mathbf{3}$ & 2,5 & $\mathbf{6}$ & 1 & & \\
\hline
\end{tabular}

\section{Задача 15}

\begin{tabular}{|c|c|c|c|}
\hline $\begin{array}{c}\text { Номер } \\
\text { вопроса }\end{array}$ & $\begin{array}{c}\text { Правильный } \\
\text { ответ }\end{array}$ & $\begin{array}{c}\text { Номер } \\
\text { вопроса }\end{array}$ & $\begin{array}{c}\text { Правильный } \\
\text { ответ }\end{array}$ \\
\hline $\mathbf{1}$ & 2 & $\mathbf{4}$ & $4,5,6,7$ \\
\hline $\mathbf{2}$ & 2 & $\mathbf{5}$ & 6 \\
\hline $\mathbf{3}$ & 3,4 & & \\
\hline
\end{tabular}


Задача 16

\begin{tabular}{|c|c|c|c|}
\hline $\begin{array}{c}\text { Номер } \\
\text { Вопроса }\end{array}$ & $\begin{array}{c}\text { Правильный } \\
\text { ответ }\end{array}$ & $\begin{array}{c}\text { Номер } \\
\text { вопроса }\end{array}$ & $\begin{array}{c}\text { Правильный } \\
\text { ответ }\end{array}$ \\
\hline $\mathbf{1}$ & 1 & $\mathbf{4}$ & $1,4,5,6,7$ \\
\hline $\mathbf{2}$ & 1,4 & $\mathbf{5}$ & $4,5,6$ \\
\hline $\mathbf{3}$ & $2,3,5$ & & \\
\hline
\end{tabular}

Задача 17

\begin{tabular}{|c|c|c|c|}
\hline $\begin{array}{c}\text { Номер } \\
\text { Вопроса }\end{array}$ & $\begin{array}{c}\text { Правильный } \\
\text { ответ }\end{array}$ & $\begin{array}{c}\text { Номер } \\
\text { вопроса }\end{array}$ & $\begin{array}{c}\text { Правильный } \\
\text { ответ }\end{array}$ \\
\hline $\mathbf{1}$ & 2 & $\mathbf{4}$ & 3 \\
\hline $\mathbf{2}$ & $1,2,5,6$ & $\mathbf{5}$ & $1,4,6$ \\
\hline $\mathbf{3}$ & 1,3 & & \\
\hline
\end{tabular}

Задача 18

\begin{tabular}{|c|c|c|c|}
\hline $\begin{array}{c}\text { Номер } \\
\text { вопроса }\end{array}$ & $\begin{array}{c}\text { Правильный } \\
\text { ответ }\end{array}$ & $\begin{array}{c}\text { Номер } \\
\text { вопроса }\end{array}$ & $\begin{array}{c}\text { Правильный } \\
\text { ответ }\end{array}$ \\
\hline $\mathbf{1}$ & 3 & $\mathbf{4}$ & 3 \\
\hline $\mathbf{2}$ & $2,3,4,5$ & $\mathbf{5}$ & 1,2 \\
\hline $\mathbf{3}$ & 1,3 & $\mathbf{6}$ & $4,5,6,7$ \\
\hline
\end{tabular}

Задача 19

\begin{tabular}{|c|c|c|c|}
\hline $\begin{array}{c}\text { Номер } \\
\text { вопроса }\end{array}$ & $\begin{array}{c}\text { Правильный } \\
\text { ответ }\end{array}$ & $\begin{array}{c}\text { Номер } \\
\text { вопроса }\end{array}$ & $\begin{array}{c}\text { Правильный } \\
\text { ответ }\end{array}$ \\
\hline $\mathbf{1}$ & 3 & $\mathbf{4}$ & 2,6 \\
\hline $\mathbf{2}$ & $2,3,4,5$ & $\mathbf{5}$ & 1 \\
\hline $\mathbf{3}$ & 1,3 & $\mathbf{6}$ & 2 \\
\hline
\end{tabular}

Задача 20

\begin{tabular}{|c|c|c|c|}
\hline $\begin{array}{c}\text { Номер } \\
\text { вопроса }\end{array}$ & $\begin{array}{c}\text { Правильный } \\
\text { ответ }\end{array}$ & $\begin{array}{c}\text { Номер } \\
\text { вопроса }\end{array}$ & $\begin{array}{c}\text { Правильный } \\
\text { ответ }\end{array}$ \\
\hline $\mathbf{1}$ & 1 & $\mathbf{4}$ & 1 \\
\hline $\mathbf{2}$ & $2,3,4,5$ & $\mathbf{5}$ & 1 \\
\hline $\mathbf{3}$ & 2,4 & & \\
\hline
\end{tabular}




\section{РЕКОМЕНДУЕМАЯ ЯИТЕРАТУРА}

\section{Основная}

1. Внутренние болезни в 2-х томах: учебник / Под ред. Н.А. Мухина - М.: ГЭОТАР-Медиа, 2008.

2. Маколкин В.И., Овчаренко С.И. Внутренние болезни: Учебник. 4-е изд., перераб. и доп. - М.: Медицина, 2005.

3. Внутренние болезни в вопросах и ответах: Учебное пособие для медицинских вузов / под ред. проф. Ю.Р. Ковалева. - СПб.: ООО «Издательство ФОЛИАНТ», 2004.

\section{Дополнительная}

1. Кардиология: Национальное руководство / Под ред. Ю.Н. Беленкова, Р.Г. Оганова. - М.: ГЭОТАР-Медиа, 2010.

2. Окороков А.Н. Руководство по лечению внутренних болезней: 3-е изд. перераб. и доп., Т. 2-3. - М.: Мед. Лит., 2008-2010.

3. Национальные рекомендации ОССН, РКО и РНМОТ по диагностике и лечению хронической сердечной недостаточности (4 пересмотр) // Сердечная недостаточность. - 2013. - Т. 14, № 7(81). C. $379-472$.

4. Диагностика и лечение фибрилляции предсердий. Рекомендации PКО, ВНОК, АССХ. Российский кардиологический журнал 2013; 4(102) прилоожение 3.

5. Рекомендации по лечению Артериальной Гипертонии ESH/ESC 2013 Российский кардиологический журнал 2014 № 1(105) c.7-94.

6. Рекомендации по электрокардиостимуляции и сердечной ресинхронизирующей терапии ESC 2013 Российский кардиологический журнал 2014 № 4(108) с. 5-63.

7. Третье универсальное определение инфаркта Российский кардиологический журнал 2013; 2(100) приложение 1.

8. Национальные рекомендации по кардиоваскулярной профилактике Первое издание 2011. Кардиоваскулярная терапия и профилактика 2011; 10 (6) Приложение 2. 
9. Национальные рекомендации по прогнозированию и профилактике кардиальных осложнений внесердечных хирургических вмешательств у кардиологических больных Первое издание 2011. Кардиоваскулярная терапия и профилактика 2011; 10 (6) Приложение 3.

10. Рекомендации по диагностике и лечению ТЭЛА Рациональная фаркмакотерапия в кардиологии 2009 № 1 с96-111.

11. Рекомендации по лечению Острого коронарного синдрома без стойких подъхемов сегмента ST Рациональная фаркмакотерапия в кардиологии 2012 приложение № 2. 
Учебное издание

Наумова Елизавета Александровна

Шварц Юрий Григорьевич

Железнякова Наталия Александровна

Семенова Ольга Никоолаевна

\section{ТЕСТЫ И ЗАДАЧИ ПО КАРДИОЛОГИИ}

Учебное пособие

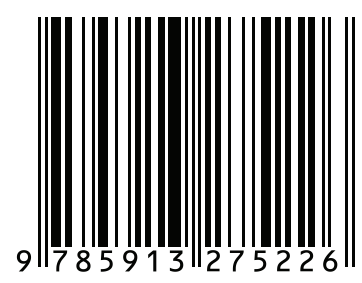

Технический редактор Кулакова Г.А.

Подписано в печать 16.04.2018

Бумага офсетная.

Гарнитура NewtonC

Формат $60 \times 841 / 16$

Печать трафаретная. Печ. л. 5,63.

Тираж 500 экз. Заказ № 009-18.

Отпечатано в типографии ИД «Академия Естествознания», 440026, г. Пенза, ул. Лермонтова, 3 